\title{
Climatic Experiment on Guizhou Red Heart Kiwifruit Ulcer Disease
}

\author{
Zaixiang Chi ${ }^{1}$, Xianju Long2 ${ }^{*}$, Zhengjing Du ${ }^{3}$, Xiang Sun${ }^{1}$, Qiuling Hu${ }^{4}$, Yuan Long1 \\ ${ }^{1}$ Liupanshui Meteorological Bureau of Guizhou Province, Liupanshui, China \\ ${ }^{2}$ Southeast Guizhou Prefecture Meteorological Bureau of Guizhou Province, Kaili, China \\ ${ }^{3}$ Guizhou Meteorological Service Center, Guiyang, China \\ ${ }^{4}$ Liupanshui City Plant Inspection and Protection Station of Guizhou Province, Liupanshui, China \\ Email: *qxxf_850@163.com
}

How to cite this paper: Chi, Z. X., Long, X. J., Du, Z. J., Sun, X., Hu, Q. L., \& Long, Y. (2019). Climatic Experiment on Guizhou Red Heart Kiwifruit Ulcer Disease. Journal of Geoscience and Environment Protection, 7, 251-273.

https://doi.org/10.4236/gep.2019.74017

Received: September 20, 2018

Accepted: April 27, 2019

Published: April 30, 2019

Copyright $\odot 2019$ by author(s) and Scientific Research Publishing Inc. This work is licensed under the Creative Commons Attribution International License (CC BY 4.0).

http://creativecommons.org/licenses/by/4.0/

\begin{abstract}
Using the climatic data, such as extreme minimum temperature and relative humidity, in 15 bases in the main planting area of Guizhou Red Heart Kiwifruit from December 1st to next April 30th, respectively, from 2010 to 2018, combined with the monitoring of red heart kiwifruit ulcer disease, we analyze the occurrence and prevalence of meteorological factors and dynamic characteristics of the red heart kiwifruit ulcer disease in Guizhou, China. The results showed that the main period of occurrence and prevalence of red heart kiwifruit ulcer was from March to April. In winter, when the daily average temperature of $5 \mathrm{~d}$ and above is $\leq 2^{\circ} \mathrm{C}$, the daily extreme minimum temperature is $\leq-2^{\circ} \mathrm{C}$, and the daily average relative humidity is $\geq 75 \%$, it is beneficial for the ulcer pathogen to lurk and propagate in the plant. It is suggested that this meteorological condition should be used as an early warning indicator for the prevention of ulcer disease of red heart kiwifruit, in order to actively organize prevention after the emergence of early warning indicators to improve the prevention and treatment effect. In spring, the average daily temperature of $5 \mathrm{~d}$ and above is $\leq 18^{\circ} \mathrm{C}$, and the daily average relative humidity is $\geq 80 \%$, which is easy to induce ulcer disease. It can be seen that the first is the winter climatic conditions to meet the breeding of ulcer disease, and then the spring climatic conditions must also meet the rapid propagation of ulcer disease, ulcer disease can occur, develop and popularize. It is of great practical significance to carry out experiments on the relationship between the occurrence of ulcer disease in Guizhou red heart kiwifruit and meteorological conditions.
\end{abstract}

\section{Keywords}

Red Heart Kiwifruit, Ulcer Disease, Temperature Condition, Humidity Condition 


\section{Introduction}

Kiwifruit ulcer disease is a worldwide devastating bacterial disease caused by Pseudomonas syringae. Many experts and scholars (Serizawa \& Ichikawa, 1993; Hyo et al., 2003; Balestr et al., 2010; Liu et al., 1996; Zhang, 2011) studied the pathogens of kiwi bacterial ulcer disease, and the results showed that the pathogens were Pseudomonas syringae kiwifruit-induced disease (PSA) strains.

In recent years, with the implementation of large-scale kiwifruit cultivation in Guizhou Province, ulcer disease has also occurred. Individual cultivation areas have cut trees in large areas and the losses are serious. Most experts and scholars mainly study the causes and control measures of kiwifruit pests and diseases. For example, Wang (2015) monitored and investigated the red kiwifruit ulcer disease in the spring of 2012-2014. It is concluded that the occurrence of ulcer disease is mainly due to sufficient sources, low temperature and damp climate conditions and extensive management. Han et al. (2013) studied the factors affecting the occurrence of kiwifruit ulcer disease, and found that when the extreme low temperature reached $-12^{\circ} \mathrm{C}$ or below, the disease occurred within 5 days, and the low temperature and rainy rain caused the ulcer disease to increase in March. Li et al. (2001) obtained the meteorological factors affecting the degree of ulcer disease through analysis, which is the precipitation in mid-to-late March and the average temperature in January. Serizawa \& Ichikawa (1993) confirmed that the rainy, high-humidity and low-temperature $\left(12^{\circ} \mathrm{C}-18^{\circ} \mathrm{C}\right)$ climate in early spring in Italy is conducive to the rapid propagation of PSA pathogens. When the temperature is raised to $25^{\circ} \mathrm{C}$, the harm of pathogens is weakened. Therefore, it is of great practical significance to carry out the experiment on the relationship between the occurrence of ulcer disease in Guizhou red heart kiwifruit and meteorological conditions.

\section{Materials and Methods}

\subsection{Test Location and Materials}

Select the Kiwifruit farm town of Shuicheng County, the main planting area of Guizhou red heart kiwifruit (1100 m above sea level, $105^{\circ} 07^{\prime} \mathrm{E}, 26^{\circ} 13^{\prime} \mathrm{N}$, referred to as Kiwifruit Farm, the same below), Micheng Town, Shuicheng County (1100 $\mathrm{m}, 104^{\circ} 59^{\prime} \mathrm{E}, 26^{\circ} 22^{\prime} \mathrm{N}$, referred to as rice bran, the same below), Shulong Town, Shuicheng County $\left(1200 \mathrm{~m}, 105^{\circ} 06^{\prime} \mathrm{E}, 26^{\circ} 20^{\prime} \mathrm{N}\right.$, referred to as Xiaolong, the same below), Jichang Township, Shuicheng County (Elevation $1250 \mathrm{~m}, 104^{\circ} 39^{\prime} \mathrm{E}$, $26^{\circ} 16^{\prime} \mathrm{N}$, referred to as chicken farm, the same below), Shuicheng County Faer Township (1200 m, $104^{\circ} 45^{\prime} \mathrm{E}, 26^{\circ} 18^{\prime} \mathrm{N}$, referred to as ear, lower Same), Yangmei Township, Shuicheng County $\left(1400 \mathrm{~m}, 104^{\circ} 48^{\prime} \mathrm{E}, 26^{\circ} 16^{\prime} \mathrm{N}\right.$, referred to as Yangmei, the same below), Shuimi Town, Shuicheng County (1400 m, 104 ${ }^{\circ} 48^{\prime} \mathrm{E}$, $26^{\circ} 28^{\prime} \mathrm{N}$ ), referred to as spoon rice, the same as), Shunchang Township, Shuicheng County $\left(1350 \mathrm{~m}, 104^{\circ} 49^{\prime} \mathrm{E}, 26^{\circ} 09^{\prime} \mathrm{N}\right.$, referred to as the field, the same below), Langzhi Town, Liuzhi District (1345 m, $105^{\circ}$ above sea level) $27^{\prime} \mathrm{E}$, $26^{\circ} 04^{\prime} \mathrm{N}$, referred to as Langqi, the same below), Pugu Township, Panzhou City 
(1300 $\mathrm{m}, 104^{\circ} 31^{\prime} \mathrm{E}, 26^{\circ} 05^{\prime} \mathrm{N}$, referred to as Pugu, the same below), Pu'an County Woxiang Township (1220 $\mathrm{m}$ above sea level, $104^{\circ} 56^{\prime} \mathrm{E}, 25^{\circ} 52^{\prime} \mathrm{N}$, Referred to as the nest, the same as), Sansui County Changji Township ( $80 \mathrm{~m}, 108^{\circ} 45^{\prime} \mathrm{E}$, $26^{\circ} 57^{\prime} \mathrm{N}$, referred to as Changji, the same below), Sanma County Roller Township ( $645 \mathrm{~m}, 108^{\circ}$ above sea level) $37^{\prime} \mathrm{E}, 26^{\circ} 57^{\prime} \mathrm{N}$, referred to as Rolling Horse, the same below), Yangbingtang Town, Shibing County $(781 \mathrm{~m}$ above sea level, $108^{\circ} 09^{\prime} \mathrm{E}, 26^{\circ} 56^{\prime} \mathrm{N}$, referred to as Yangliutang, the same below), Shi Bing County Chengguan Town (Elevation $625 \mathrm{~m}, 108^{\circ} 05^{\prime} \mathrm{E}, 27^{\circ} 04^{\prime} \mathrm{N}$, referred to as Chengguan, the same below). The kiwifruit product tested was Hongyang.

\subsection{Test Methods}

In the spring of 2011-2018, in the Kiwifruit field, rice bran, oyster dragon, chicken farm, ear, yangmei, spoon rice, Shunchang, Langqi, Pugu, Woyan, Changji, Rolling Horse, Yangliutang, Chengguan A total of 15 bases for the dynamic observation of ulcer disease in red heart kiwifruit, combined with the average daily temperature, extreme minimum temperature and average relative humidity data of the base automatic weather station from December 1st to April 30th of 2010-2018 The relationship between meteorological factors and the occurrence, development and prevalence of pink kiwifruit ulcer disease was determined by similar analysis method and elimination method, combined with ulcer disease monitoring, to determine the meteorological conditions of red heart kiwifruit ulcer disease.

\subsection{Monitoring the Occurrence of Ulcer Disease at a Fixed Point}

Through the spring of 2011-2018, 15 red kiwifruit monitors such as Kiwifruit Farm were found in the spring of March 2015. It was found that some red heart kiwifruit leaves were dark brown spots in the Langfang base in early March 2014, and the branches showed water stains. By the beginning of April, the leaves turned grayish white, the flower buds were brown and dead, and the branches were overflowing with pus; the Pugu base detected some dark brown spots on the leaves in late March, and the branches were watery, and the leaves became in early April. Grayish white, flower buds are brown, and branches have pus overflow; Yangmei base detected some dark brown spots on the leaves in early March, and the branches were watery. The leaves turned grayish white from late March to early April, and the flower buds were brown. And the dead, the branches have pus overflow; the scoop rice base was observed in early March, some of the leaves were dark brown spots, the branches were watery, and the leaves turned grayish white from late March to early April, the flower buds were brown and died. There is a pus overflow in the branches. From early to mid-March 2015, at the Yangmei base and the rice bran base, and in late March, the leaves of individual red hearts kiwifruit were dark brown spots and the branches were watery. In late March, the Yangmei base and the rice bran base were used. The leaves of the red heart kiwifruit turned grayish white, the flower buds were brown, and the branches had pus overflow. The leaves of the spoon 
rice base turned grayish white from early to mid-April, the flower buds were brown and dead, and the branches had pus overflow. In early March 2016, some rice leaves were found to have dark brown spots on the rice bran base, and the branches were watery, while some of the leaves were dark brown spots observed in the middle of March in Langzhong base, Pugu base, Yangmei base and scoop rice base. The branches are water-stained; the leaves of the Langji base, the Yangmei base and the spoon rice base become grayish white in late March, the flower buds are brown and dead, and the branches have pus overflow, while the Pugu base and the rice bran base are up to 4 In the second half of the month, the leaves turned grayish white, the flower buds were brown and dead, and the branches had pus overflow. In early March 2017, the rice bran base was observed to have dark brown spots on the leaves, and the branches were water-stained. However, in the middle of March, the Langqi base and the Pugu base were observed to have dark brown spots on individual leaves and water-stained branches. The leaves of the three bases in late April turned grayish white, the buds turned brown, and the branches had pus overflow. In late March 2018, some leaves were dark brown spots at the Langji base, Pugu base, scoop rice base and rice bran base, and the branches were water-stained; in early April, the leaves turned grayish and the buds turned brown. Withered, the branches have pus overflow.

\section{Results and Analysis}

Ulcer disease is a low-temperature and high-humidity infecting bacteria. It usually begins in early March and begins to be severe in late April. It slows down with increasing temperature. The severity of the disease is related to the climatic conditions of the year, the freezing damage and resistance of trees during wintering (Zhu, 2009).

\subsection{Changes in Meteorological Elements from the Winter of 2013 to the Spring of 2014 and Their Impact on Ulcer Disease}

From December 1, 2013 to February 28, 2014, there were two low-temperature and high-humidity weather processes in Langyu, which appeared in late December 2013 and the average temperature was $1.1^{\circ} \mathrm{C}-2.0^{\circ} \mathrm{C}$ for 11 consecutive days. The daily minimum temperature was $-2.9^{\circ} \mathrm{C}--2.1^{\circ} \mathrm{C}$, daily average relative humidity is $82 \%-90 \%$, and the average temperature is $-1.4^{\circ} \mathrm{C}-1.7^{\circ} \mathrm{C}$ for the last 10 days from the late to late mid-February 2014, and the daily minimum temperature is $-4.1^{\circ} \mathrm{C}--2.2^{\circ} \mathrm{C}$. The daily average relative humidity is $83 \%-$ $100 \%$ of low temperature rain and snow weather (Figure 1(a1)); Pugu has one low temperature and high humidity weather process, mainly occurring in the late February to mid mid-February 2014 and the average temperature for 7 consecutive days. It is $0.4^{\circ} \mathrm{C}-1.9^{\circ} \mathrm{C}$, the daily extreme minimum temperature is $-2.8^{\circ} \mathrm{C}--2.0^{\circ} \mathrm{C}$, and the daily average relative humidity is $81 \%-96 \%$ of low temperature rain and snow weather (Figure 1(a2)); Yangmei has two low temperature and high humidity weather processes, respectively From mid-December 


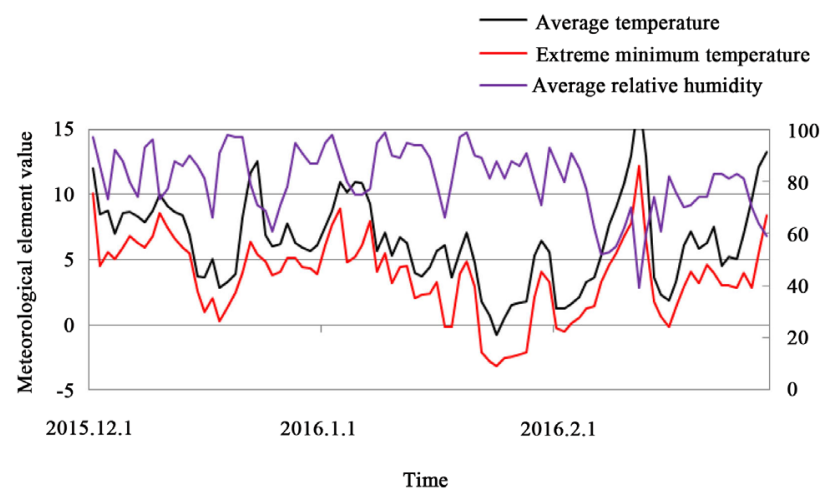

(a1)

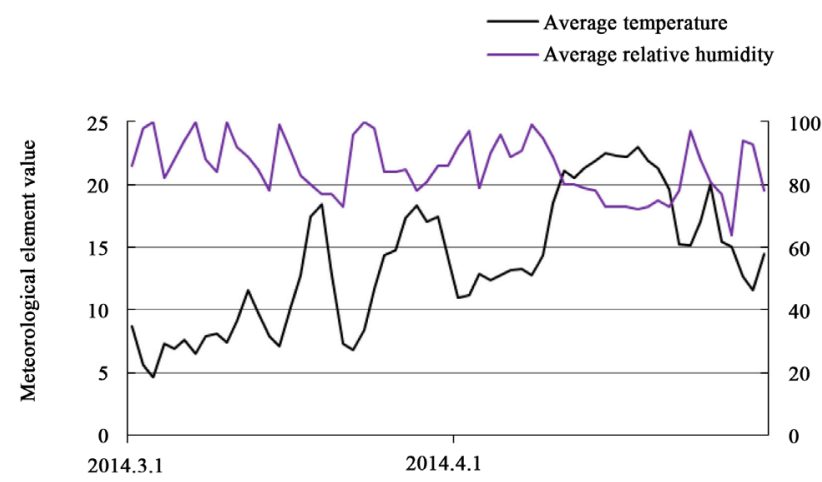

(b1)

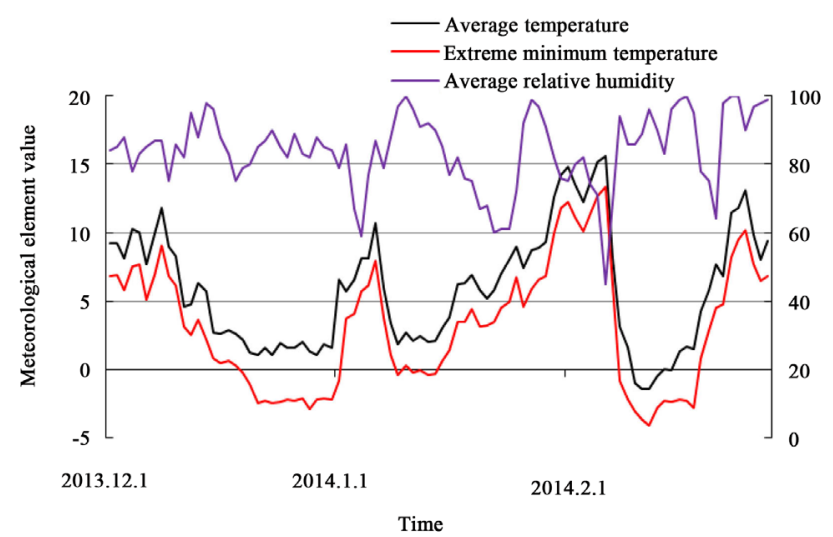

(a2)
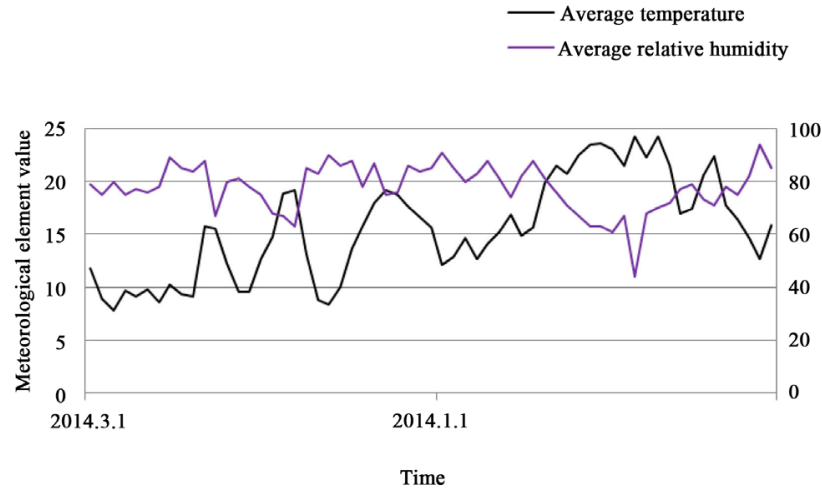

(b2) 


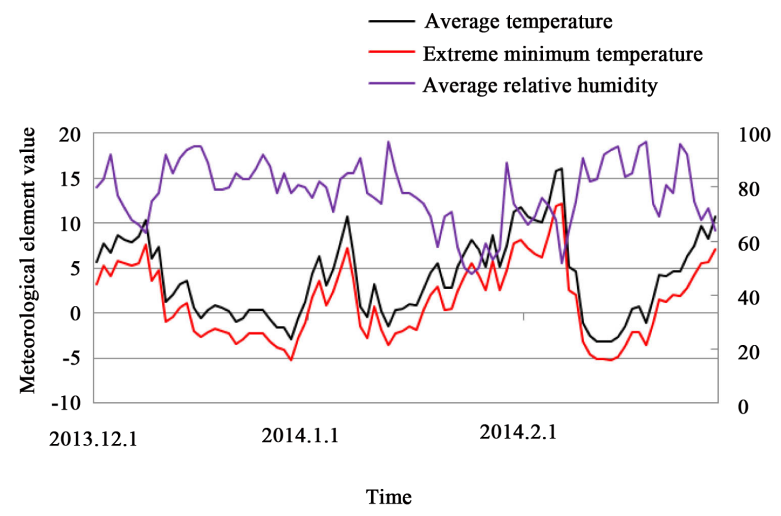

(a3)

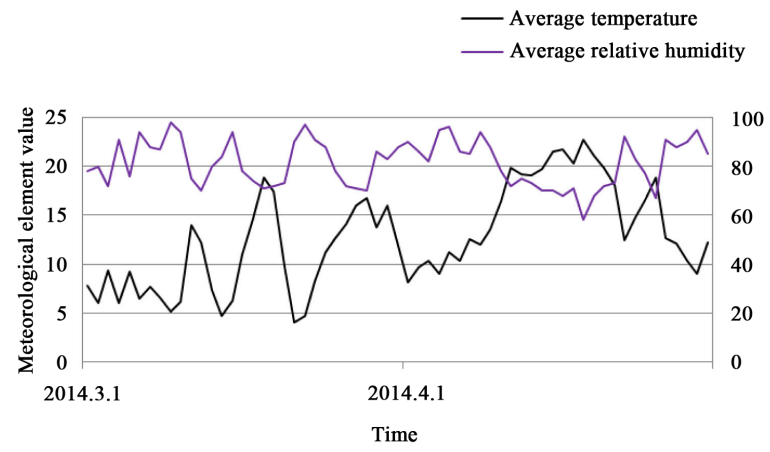

(b3)

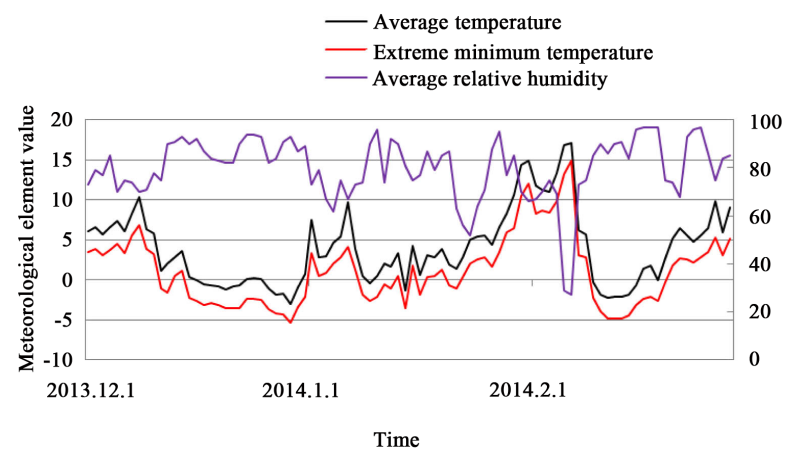

(a4)

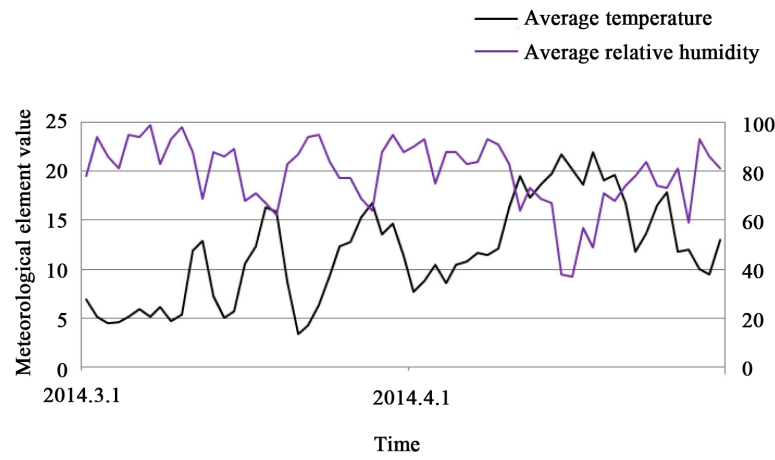

(b4)

Figure 1. Daily meteorological elements change in Langyi ((a1), (b1)), Pugu ((a2), (b2)), Yangmei ((a3), (b3)), Shaomi ((a4), (b4)) base from December 2013 to April 2014 (unit: temperature is ${ }^{\circ} \mathrm{C}$ Relative humidity is \%). 
to mid-late December 2013 , the average daily temperature was $-2.9^{\circ} \mathrm{C}$ to $0.9^{\circ} \mathrm{C}$ for 16 consecutive days, the minimum daily temperature was $-5.2^{\circ} \mathrm{C}$ to $-1.7^{\circ} \mathrm{C}$, and the daily average relative humidity was $78 \%$ to $95 \%$ and February 2014 . The average temperature from the late 10 th to the late 10 th day is $-3.2^{\circ} \mathrm{C}-0.8^{\circ} \mathrm{C}$, and the daily extreme minimum temperature is $-5.2^{\circ} \mathrm{C}--2.1^{\circ} \mathrm{C}$, daily average relative humidity of $82 \%-97 \%$ of low temperature rain and snow weather (Figure 1(a3)); appeared in mid-December 2013 to the end of the late 17 th day and the average temperature of $-3.0^{\circ} \mathrm{C}-0.8^{\circ} \mathrm{C}$ for $17 \mathrm{~d}$, The daily minimum temperature is $-5.4^{\circ} \mathrm{C}$ to $-2.1^{\circ} \mathrm{C}$, the daily average relative humidity is $82 \%$ to $94 \%$, and the average temperature for the last 10 days from the late to late mid-February 2014 is $-2.3^{\circ} \mathrm{C}$ to $1.8^{\circ} \mathrm{C}$, and the daily minimum temperature is $-4.9^{\circ} \mathrm{C}$ to $-2.1^{\circ} \mathrm{C}$, daily average relative humidity of $85 \%$ to $97 \%$ of low temperature rain and snow weather (Figure 1(a4)). It can be seen that the low temperature and high humidity conditions in winter are suitable for the latent, proliferating and spreading of the pathogens of ulcer disease, which creates favorable conditions for the occurrence, development and popularization of spring ulcer disease. The extreme minimum temperature curve is only analyzed during the winter (December to March).

From March 1st to April 30th, 2014, there were 4 low-temperature and high-humidity weather processes in Langyu, which occurred in the first half of March to the middle of the first period and the average temperature was $4.6^{\circ} \mathrm{C}$ $11.6^{\circ} \mathrm{C}$ for 13 consecutive days, and the daily average relative humidity was $82 \%$ - $100 \%$, the average temperature for the 6 th day in late March is $6.8^{\circ} \mathrm{C}-1.73^{\circ} \mathrm{C}$, the daily average relative humidity is $84 \%-100 \%$, and the average daily temperature is $11.0^{\circ} \mathrm{C}-17.4^{\circ} \mathrm{C}$ for the 5 th day from the late March to the beginning of April. The daily average relative humidity is $81 \%-97 \%$, and the average temperature of the average temperature in the first half of April is $12.8^{\circ} \mathrm{C}-14.4^{\circ} \mathrm{C}$ and the daily average relative humidity is $89 \%$ - 99\% (Figure 1(b1)); Two times of low-temperature and high-humidity weather occurred, which occurred in late March and averaged $8.4^{\circ} \mathrm{C}$ to $13.7^{\circ} \mathrm{C}$ for 5 consecutive days, daily average relative humidity of $83 \%$ to $90 \%$, and late March to mid-April for 9 days. The average temperature is $12.1^{\circ} \mathrm{C}-17.6^{\circ} \mathrm{C}$, and the daily average relative humidity is $80 \%-91 \%$ in low temperature and high humidity weather (Figure 1(b2)). The three low temperature and high humidity weather occurs in Yangmei, which occurs in early March and lasts for 5 days. The temperature is $5.1^{\circ} \mathrm{C}$ to $7.7^{\circ} \mathrm{C}$, and the daily average relative humidity is $87 \%$ to $98 \%$. After the end of March By the end of the first ten days of April, the average daily temperature was $8.1^{\circ} \mathrm{C}$ to $16.0^{\circ} \mathrm{C}$, the daily average relative humidity was $82 \%$ to $96 \%$, and the average daily temperature was $9.0^{\circ} \mathrm{C}$ to $12.7^{\circ} \mathrm{C}$ for 5 consecutive days in late April, and the daily average relative humidity was $85 \%$ to $91 \%$ low temperature and high humidity weather (Figure 1(b3)); 4 times of low temperature and high humidity weather occurred in spoon rice, which appeared in early March to early mid-March and averaged $4.5^{\circ} \mathrm{C}$ to $11.9^{\circ} \mathrm{C}$ for 10 consecutive days, and daily average relative humidity was $81 \%-98 \%$, in the middle and late March, the aver- 
age daily temperature for the 5 th day is $3.4^{\circ} \mathrm{C}-9.4^{\circ} \mathrm{C}$, and the daily average relative humidity is $83 \%-95 \%$. The average temperature for the 5 th day from the late March to the beginning of April is $7.7^{\circ} \mathrm{C}-14.7^{\circ} \mathrm{C}$. The daily average relative humidity is $88 \%$ to $95 \%$, and the average daily temperature in the first 7 days of April is $8.6^{\circ} \mathrm{C}$ to $16.3^{\circ} \mathrm{C}$, and the daily average relative humidity is $83 \%$ to $93 \%$ (Figure 1(b4)). Therefore, suitable temperature and humidity conditions in spring promote the spread of ulcer disease and increase the degree of harm.

\subsection{Changes in Meteorological Elements during the Winter of 2014 to the Spring of 2015 and Their Impact on Ulcer Disease}

From December 1, 2014 to February 28, 2015, Yangmei had two low-temperature and high-humidity weather processes, which occurred in mid-December 2014 and the average temperature was $-2.0^{\circ} \mathrm{C}$ to $1.0^{\circ} \mathrm{C}$ for 8 consecutive days. $-4.3^{\circ} \mathrm{C}$ $-2.0^{\circ} \mathrm{C}$, daily average relative humidity is $90 \%-95 \%$, and the average temperature is $0.0^{\circ} \mathrm{C}-1.4^{\circ} \mathrm{C}$ for 13 consecutive days from late January to early February 2015 , and the daily extreme minimum temperature is $-3.0^{\circ} \mathrm{C}--1.5^{\circ} \mathrm{C}$. The daily average relative humidity is $91 \%-98 \%$ of low temperature rain and snow weather (Figure 2(a1)); the spoon rice has two low temperature and high humidity weather processes, which occur in mid-December 2014 and the average temperature is $-1.7 \sim$ for 8 consecutive days. At $0.6^{\circ} \mathrm{C}$, the daily minimum temperature is $-4.7^{\circ} \mathrm{C}$ to $-2.5^{\circ} \mathrm{C}$, the daily average relative humidity is $85 \%$ to $97 \%$, and the average temperature is $-0.7^{\circ} \mathrm{C}$ to $1.3^{\circ} \mathrm{C}$ for the 12 th consecutive day from the end of January to the end of February 2015. The lowest temperature is $-3.6^{\circ} \mathrm{C}$ $-2.0^{\circ} \mathrm{C}$, the daily average relative humidity is $89 \% \sim 97 \%$ of low temperature rain and snow weather (Figure 2(a2)); rice bran in mid-December 2014, the average daily temperature is $-0.7 \sim 0.8^{\circ} \mathrm{C}$ The extreme minimum temperature is $-3.2^{\circ} \mathrm{C}$ to $-2.3^{\circ} \mathrm{C}$, and the daily average relative humidity is $82 \%$ to $90 \%$ of low temperature rain and snow (Figure 2(a3)). It can be seen that the low temperature and high humidity conditions in winter are suitable for the latent, proliferating and spreading of the pathogens of ulcer disease, which creates favorable conditions for the occurrence, development and popularization of spring ulcer disease.

From March 1st to April 30th, 2015, Yangmei had four low-temperature and high-humidity weather processes, which occurred in the middle of early March to the beginning of mid-March and the average temperature was $3.8^{\circ} \mathrm{C}-11.0^{\circ} \mathrm{C}$ and the daily average relative humidity was $86 . \%-91 \%$, the average temperature for the 7 th day in late March is $8.1^{\circ} \mathrm{C}-14.0^{\circ} \mathrm{C}$, and the daily average relative humidity is $85 \%-95 \%$. The average temperature for the 5 th day from the late April to the beginning of the first half of April is $6.3^{\circ} \mathrm{C}-8.9^{\circ} \mathrm{C}$, the daily average. The relative humidity is $82 \%$ to $93 \%$, and the average daily temperature is $8 .{ }^{\circ} \mathrm{C}$ to $17.4^{\circ} \mathrm{C}$ for 11 consecutive days in late April, and the daily average relative humidity is $82 \%$ to $95 \%$ for low temperature and high humidity (Figure 2(b1)); The wet weather process occurs in late March and the average temperature is $8.1^{\circ} \mathrm{C}$ to $12.8^{\circ} \mathrm{C}$ for 7 consecutive days, and the daily average relative humidity is 


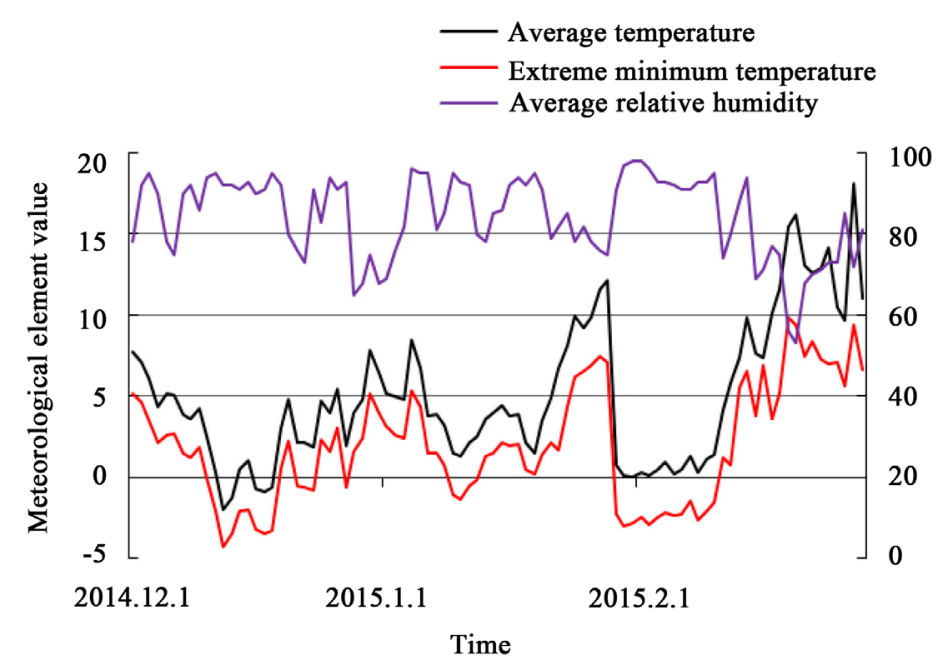

(a1)

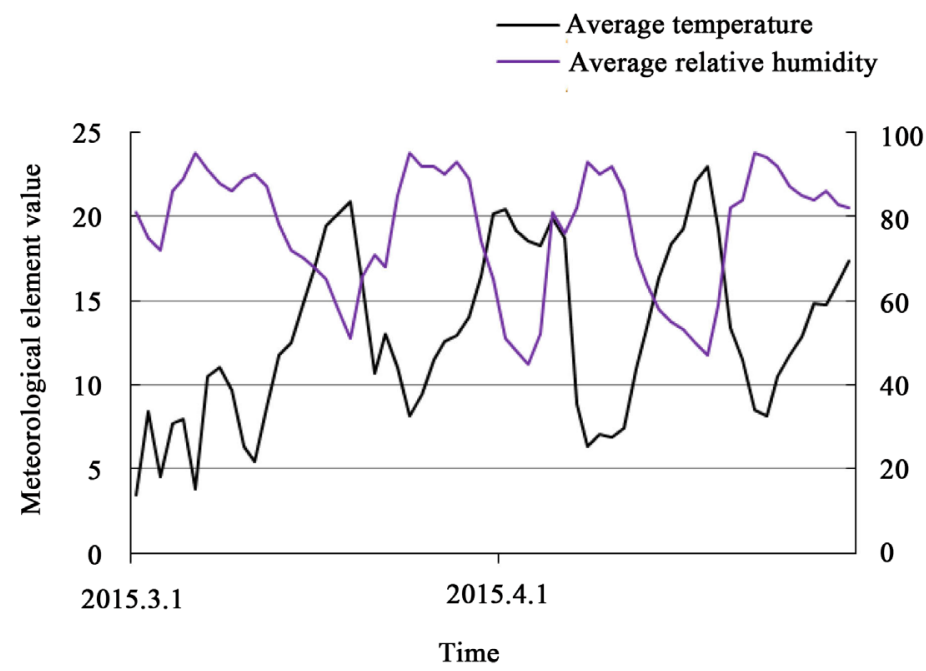

(b1)

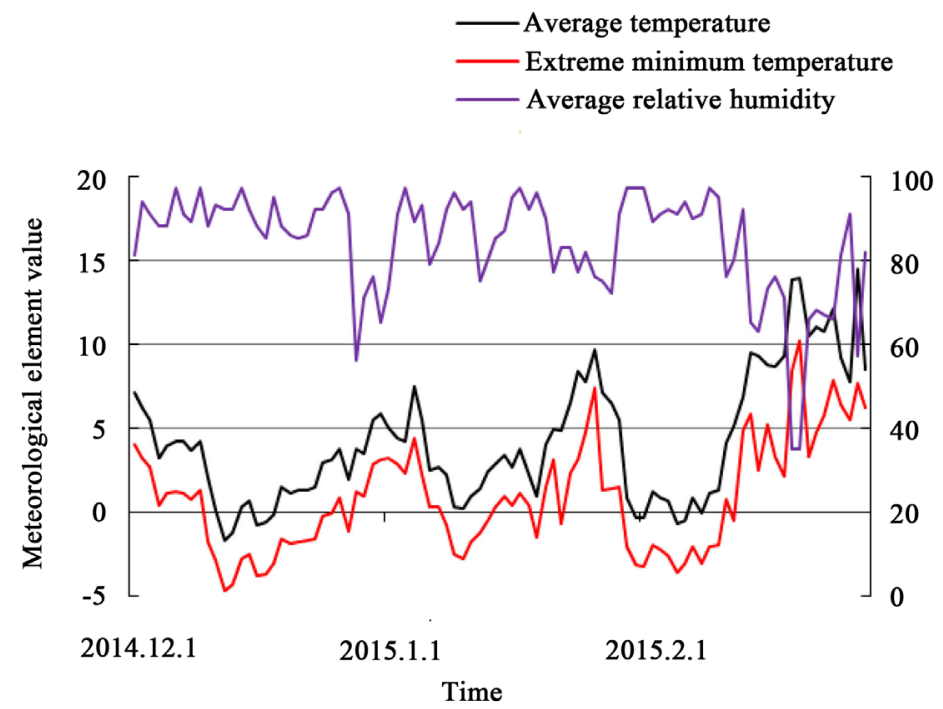

(a2) 


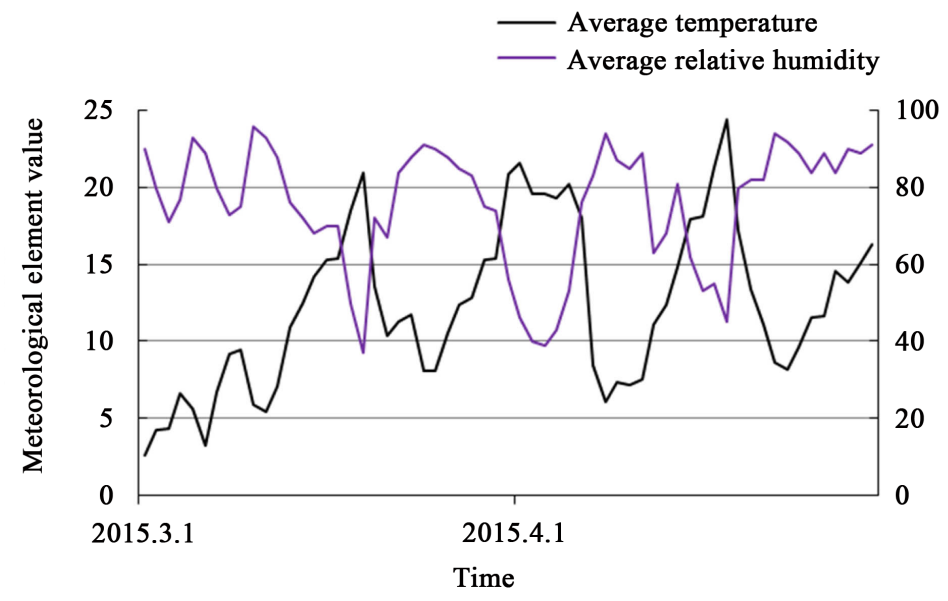

(b2)

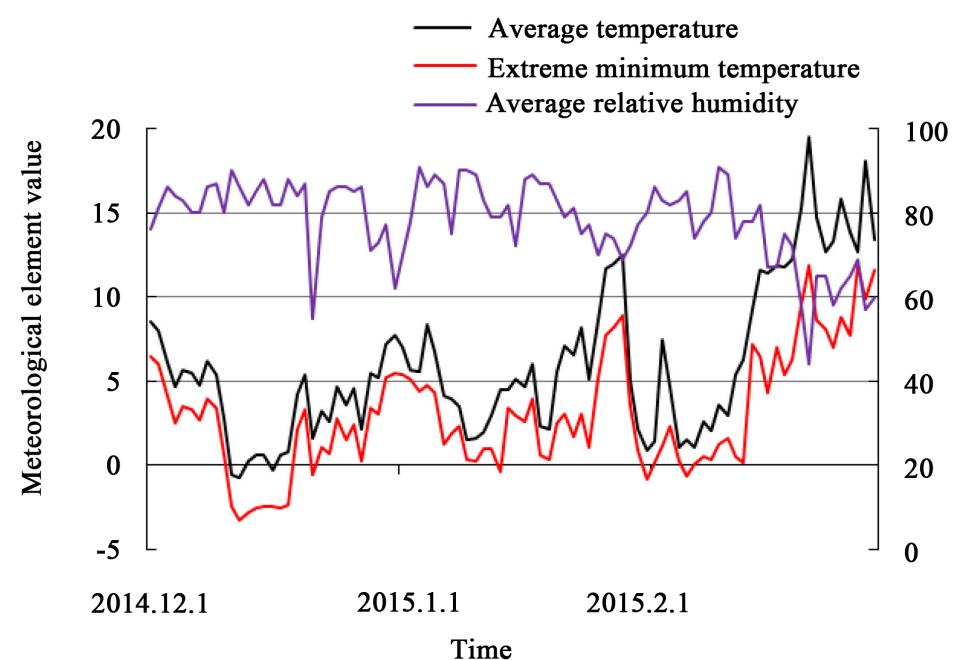

(a3)

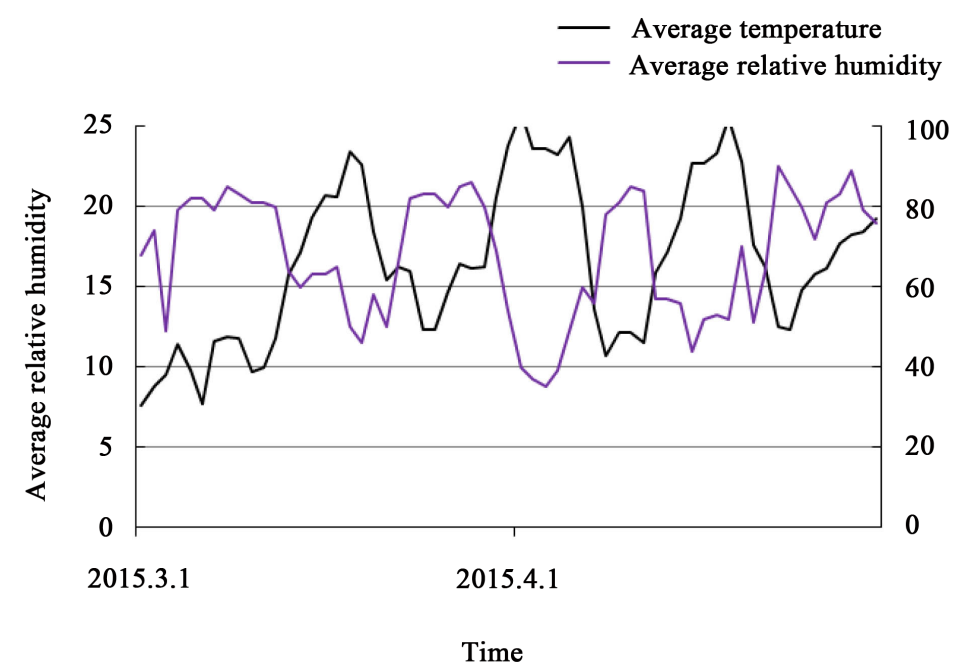

(b3)

Figure 2. Changes of meteorological elements by day from December 2014 to April 2015 in Yangmei ((a1), (b1)), Shaomi ((a2), (b2)) and Miluo ((a3), (b3)) bases (unit: temperature is ${ }^{\circ} \mathrm{C}$, relative humidity is $\left.\%\right)$. 
$83 \%$ to $91 \%$. The average temperature for the 5 th day from the late April to the beginning of the first half of April is $6.1^{\circ} \mathrm{C}$ to $8.4^{\circ} \mathrm{C}$. The daily average relative humidity is $83 \%$ to $94 \%$, and the average temperature is $8.2^{\circ} \mathrm{C}$ to $17.2^{\circ} \mathrm{C}$ for 12 consecutive days from mid-April to late April, and the daily average relative humidity is $80 \%$ to $94 \%$ for low temperature and high humidity (Figure 2(b2)); The occurrence of two low-temperature and high-humidity weather processes occurred in the late March to the early mid-March. And the average daily temperature is $9.7^{\circ} \mathrm{C}-11.9^{\circ} \mathrm{C}$ for 5 consecutive days, the daily average relative humidity is between $80 \%$ and $85 \%$, and the average daily temperature is $12.3^{\circ} \mathrm{C}$ to $16.4^{\circ} \mathrm{C}$ for 7 consecutive days in late March, and the daily average relative humidity is $80 \%$ to $85 \%$. Low temperature and high humidity weather (Figure 2 (b3)). Therefore, suitable temperature and humidity conditions in spring promote the spread of ulcer disease and increase the degree of harm.

\subsection{Changes in Meteorological Elements during the Winter of 2015 to the Spring of 2016 and Their Impact on Ulcer Disease}

From December 1, 2015 to February 29, 2016, Langxiao experienced a low-temperature and high-humidity weather process, mainly in late January 2016 and the average temperature for the 7 th day was $-0.8^{\circ} \mathrm{C}-1.8^{\circ} \mathrm{C}$, and the daily extreme minimum temperature. It is a low-temperature rain and snow weather with a daily average relative humidity of $81 \%-91 \%$ (Figure $3(\mathrm{a} 1)$ ) and a low-temperature and high-humidity weather process. It occurs mainly in late January 2016 and lasts for 7 days. The average daily temperature is $-0.9^{\circ} \mathrm{C}$ $1.9^{\circ} \mathrm{C}$, the daily extreme minimum temperature is $-2.7^{\circ} \mathrm{C}--2.0^{\circ} \mathrm{C}$, the daily average relative humidity is $80 \%-94 \%$ of low temperature rain and snow weather (Figure 3(a2)); Yangmei occurs twice low temperature and high humidity weather The process appeared in late January 2016 and the average temperature was $-6.2^{\circ} \mathrm{C}$ to $1.1^{\circ} \mathrm{C}$ for 6 consecutive days, the minimum daily temperature was $-8.0^{\circ} \mathrm{C}$ to $-2.3^{\circ} \mathrm{C}$, the daily average relative humidity was $91 \%$ to $94 \%$, and the continuous period in early February. The average daily temperature at $8 \mathrm{~d}$ is $-1.3^{\circ} \mathrm{C}$ to $1.1^{\circ} \mathrm{C}$, the minimum daily temperature is $-3.9^{\circ} \mathrm{C}$ to $-2.0^{\circ} \mathrm{C}$, and the daily average relative humidity is between $81 \%$ and $94 \%$ (Figure $3(\mathrm{a} 3)$ ); the spoon rice occurs twice. The process of low temperature and high humidity occurred in late January 2016 and the average temperature was $-6.3^{\circ} \mathrm{C}-1.8^{\circ} \mathrm{C}$ for 7 consecutive days. The degree is $-8.1{ }^{\circ} \mathrm{C}$ to $-2.0^{\circ} \mathrm{C}$, the daily average relative humidity is $91 \%$ to $96 \%$, and the average temperature for the 8th day from the end of late January to the end of February is $-1.1^{\circ} \mathrm{C}$ to $1.9^{\circ} \mathrm{C}$, and the daily minimum temperature is $-3.9^{\circ} \mathrm{C}$ to $-2.1^{\circ} \mathrm{C}$, daily average relative humidity of $86 \%$ to $98 \%$ of low temperature rain and snow weather (Figure 3(a4)); rice bran occurs once low temperature and high humidity weather process, mainly in late January 2016 and the average temperature for 5 consecutive days is $-1.1^{\circ} \mathrm{C}$ to $2.0^{\circ} \mathrm{C}$, the daily extreme minimum temperature is $-3.8^{\circ} \mathrm{C}--2.0^{\circ} \mathrm{C}$, and the daily average relative humidity is between $84 \%$ and $90 \%$ of low temperature rain and snow (Figure 3(a5)). It can be seen that the low temperature and high humidity 


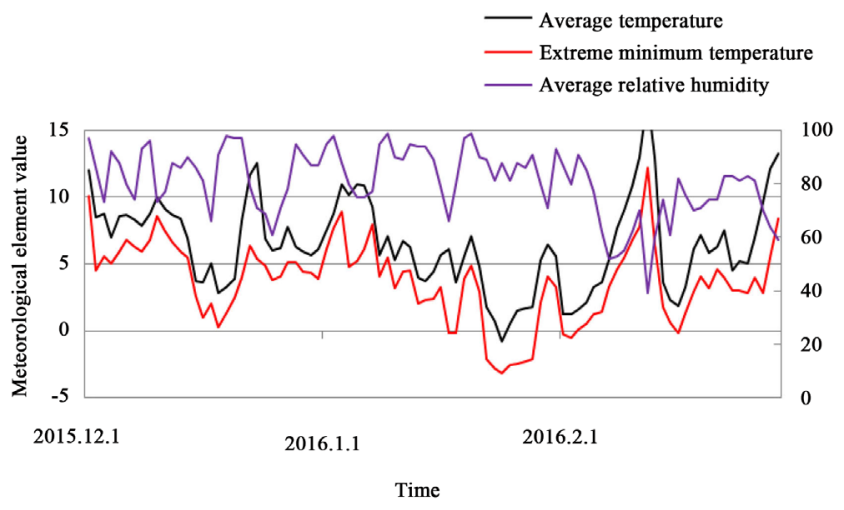

(a1)

(b1)
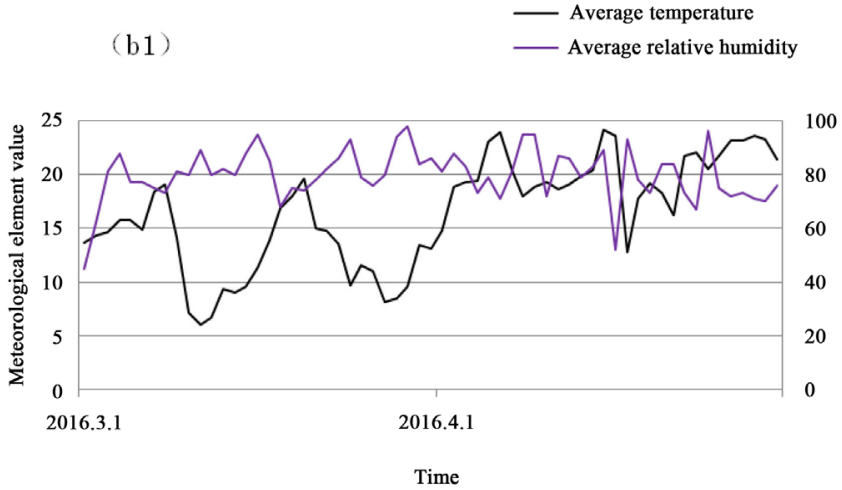

(bl)

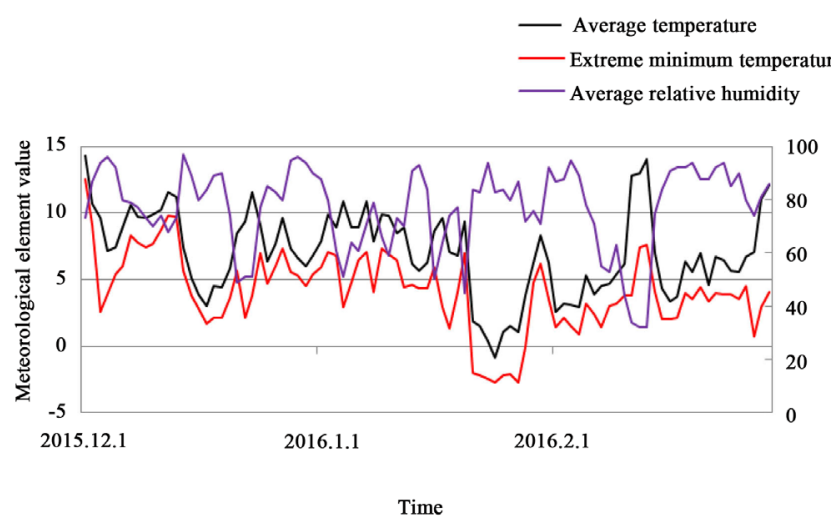

(a2)

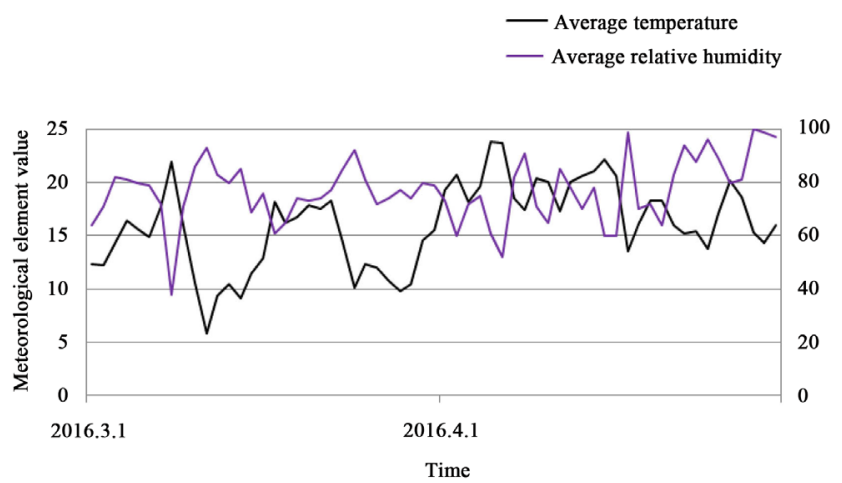

(b2) 


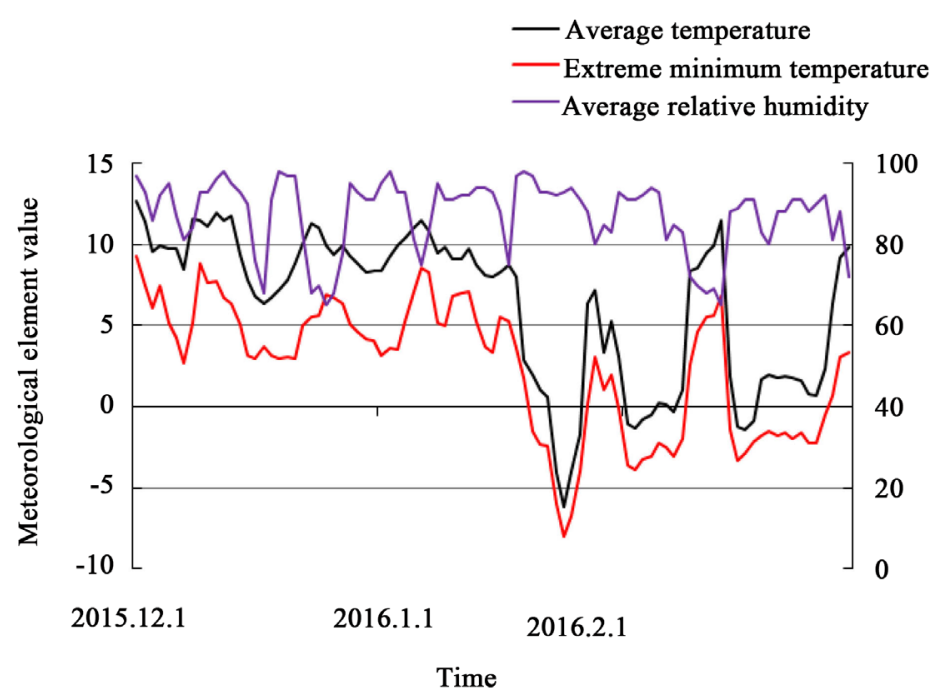

(a3)

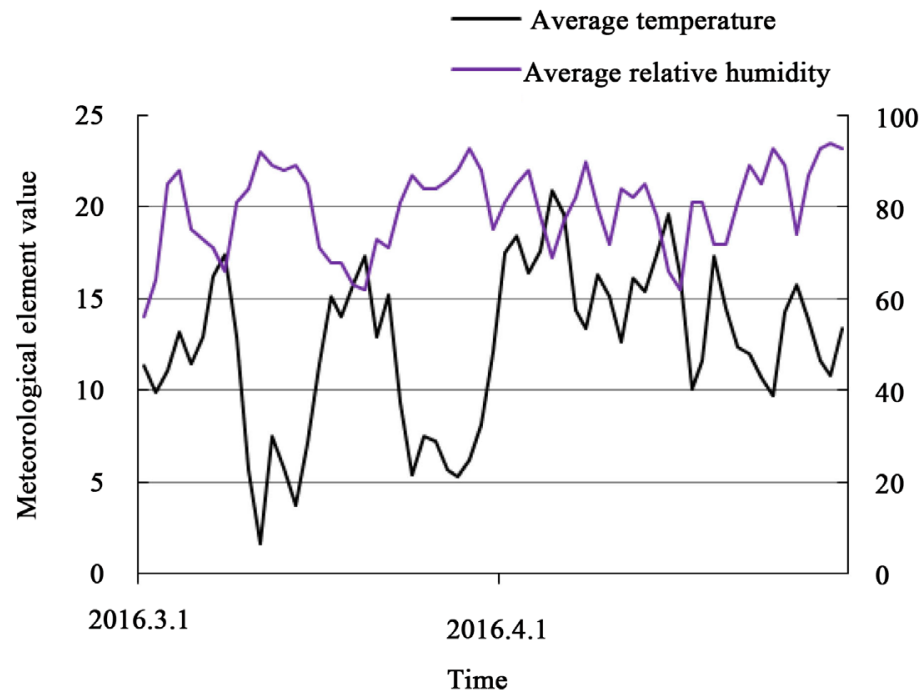

(b3)
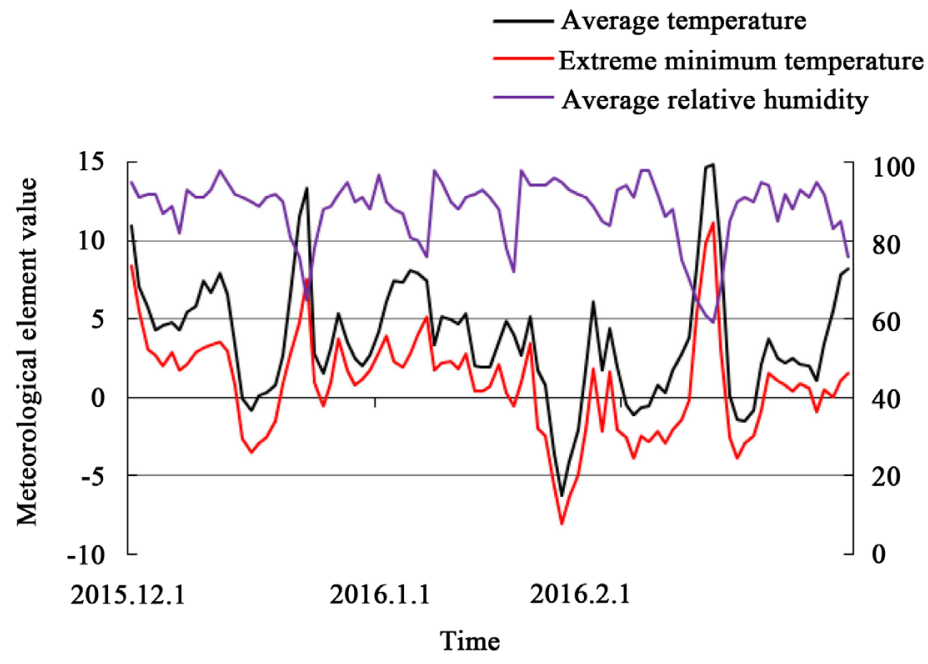

(a4) 


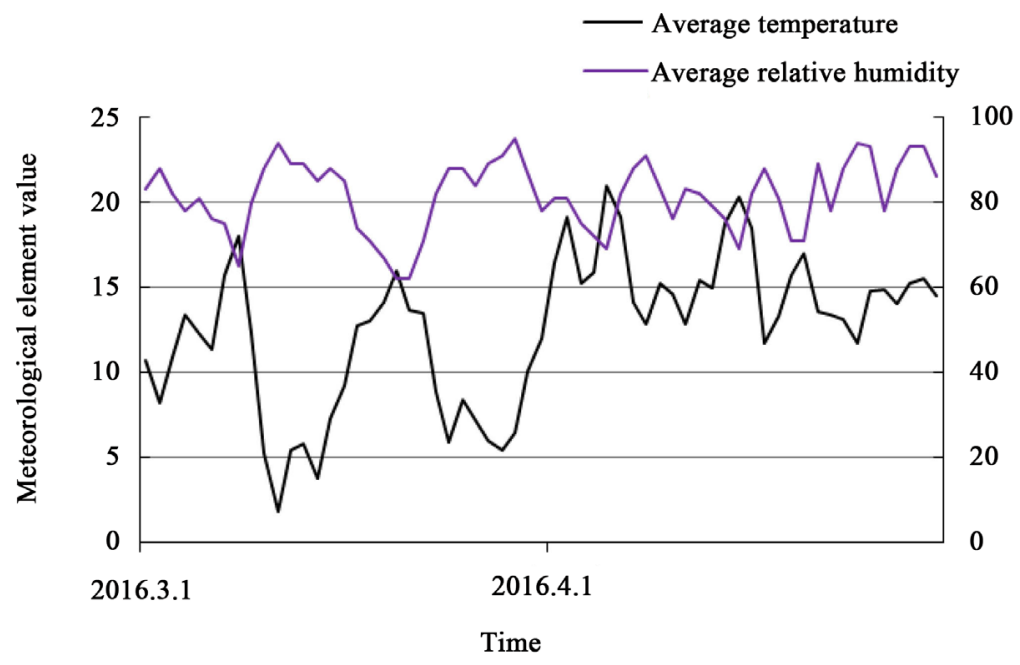

(b4)

-Average temperature

Extreme minimum temperature

-Average relative humidity

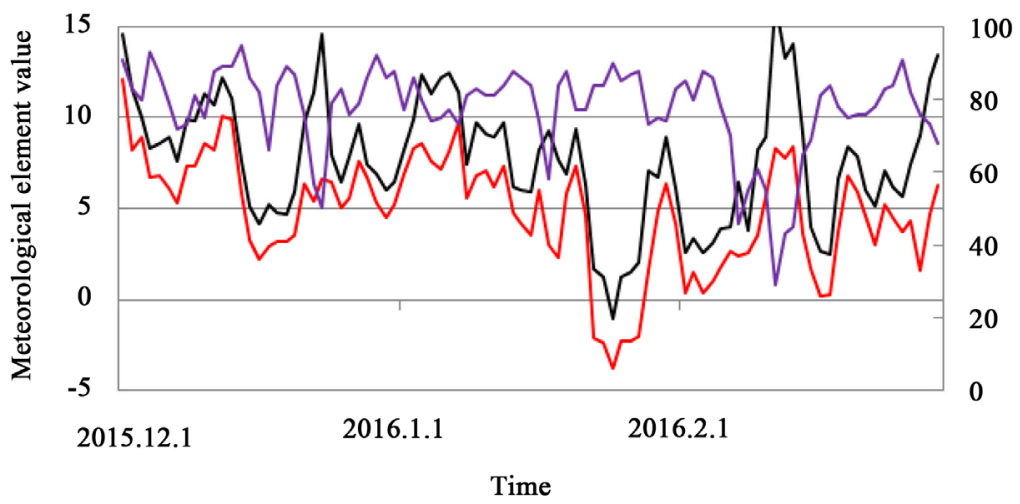

(a5)

- Average temperature

-Average relative humidity

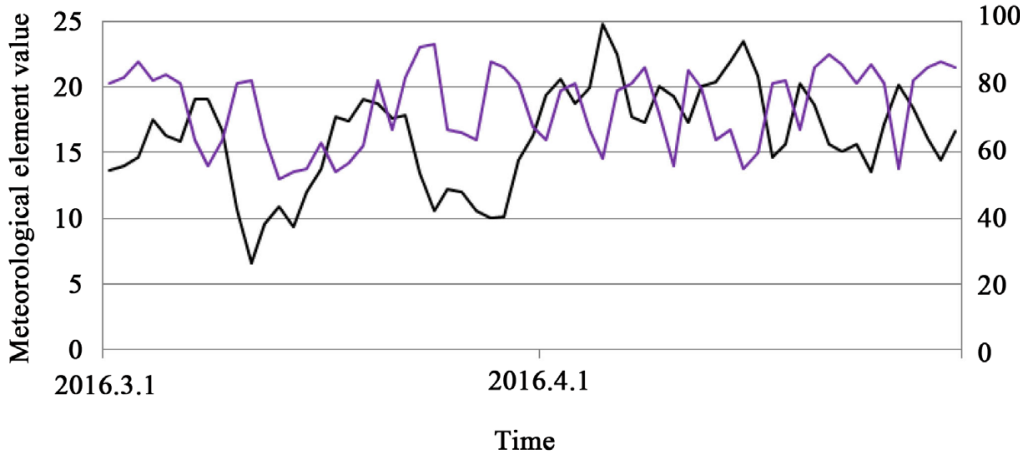

(b5)

Figure 3. Daily meteorological elements change in Langyi ((a1), (b1)), Pugu ((a2), (b2)), Yangmei ((a3), (b3)), Shaomi ((a4), (b4)) and Miluo ((a5), (b5)) bases from December 2015 to April 2016 (Unit: temperature is ${ }^{\circ} \mathrm{C}$ Relative humidity is \%). 
conditions in winter are suitable for the latent, proliferating and spreading of the pathogens of ulcer disease, which creates favorable conditions for the occurrence, development and popularization of spring ulcer disease.

From March 1st to April 30th, 2016, there were two low-temperature and high-humidity weather processes in Langyu, which appeared in the late to late mid-March period and the average temperature was $6.0^{\circ} \mathrm{C}-14^{\circ} \mathrm{C}$ for $9 \mathrm{~d}$ consecutive days. The daily average relative humidity was $80 \%-95 \%$ and the low temperature and high humidity weather with an average temperature of $8.1^{\circ} \mathrm{C}$ $14.8^{\circ} \mathrm{C}$ and a daily average relative humidity of $80 \%-98 \%$ for the continuous 6th day from the late March to the beginning of April (Figure 3(b1)); The sub-hypothermia and high-humidity weather processes occurred in the late March to the mid-March, respectively, and the average temperature was $5.8^{\circ} \mathrm{C}$ to $10.6^{\circ} \mathrm{C}$ for 5 consecutive days, the daily average relative humidity was $80 \%$ to $93 \%$, and the average temperature for the 5 th day in late April was $13.8^{\circ} \mathrm{C}$ $17.1^{\circ} \mathrm{C}$, daily average relative humidity of $83 \%-96 \%$ of low temperature and high humidity weather (Figure 3(b2)); Yangmei occurred three times of low temperature and high humidity weather, respectively, in the early March to mid-March and continuous $7 \mathrm{~d}$ daily average temperature It is $1.6^{\circ} \mathrm{C}$ to $12.9^{\circ} \mathrm{C}$, and the daily average relative humidity is between $81 \%$ and $92 \%$. The average daily temperature for the 8 th day in late March is $5.3^{\circ} \mathrm{C}$ to $9.3^{\circ} \mathrm{C}$, the daily average relative humidity is $81 \%$ to $93 \%$, and the end of April is 5 days. Low temperature and high humidity with an average temperature of $9.7^{\circ} \mathrm{C}$ to $14.3^{\circ} \mathrm{C}$ and a daily average relative humidity of $81 \%$ to $93 \%$ Gas (Figure 3(b3)); the process of two low-temperature and high-humidity weathers occurred in the spoon rice, which appeared in the late to late mid-March and lasted for 8 days, the average temperature was $1.8^{\circ} \mathrm{C}$ to $12.3^{\circ} \mathrm{C}$, and the daily average relative humidity was $80 \%$ to $94 \%$. In the second half of March, the average daily temperature was $5.4^{\circ} \mathrm{C}$ to $10.1^{\circ} \mathrm{C}$, and the daily average relative humidity was $82 \%$ to $95 \%$ (Figure 3 (b4)). The rice bran occurred twice in the low temperature and high humidity weather, which appeared in March. The average temperature in the first ten days and the continuous $6 \mathrm{~d}$ day is $13.7^{\circ} \mathrm{C}-17.5^{\circ} \mathrm{C}$, the daily average relative humidity is between $81 \%$ and $88 \%$, and the average daily temperature in the second half of April is $13.5^{\circ} \mathrm{C}-17.2^{\circ} \mathrm{C}$, and the daily average relative humidity is $81 \%-90 \%$. Low temperature and high humidity weather (Figure 3(b5)). Therefore, suitable temperature and humidity conditions in spring promote the spread of ulcer disease and increase the degree of harm.

\subsection{Changes in Meteorological Elements from the Winter of 2016 to the Spring of 2017 and Their Impact on Ulcer Disease}

From the monitoring of red heart kiwifruit ulcer disease in spring 2017, it is known that there are ulcer diseases in individual leaves of rice bran, Lang Lang and Pugu base. Combined with Figures 4(a1)-(a3) and Figures 4(b1)-(b3), in winter 2016 rice bran, lang, There was no cold rain or snow weather in the Pugu base. The meteorological conditions were not suitable for the proliferation and 
- Average temperature

- Extreme minimum temperature

- Average relative humidity

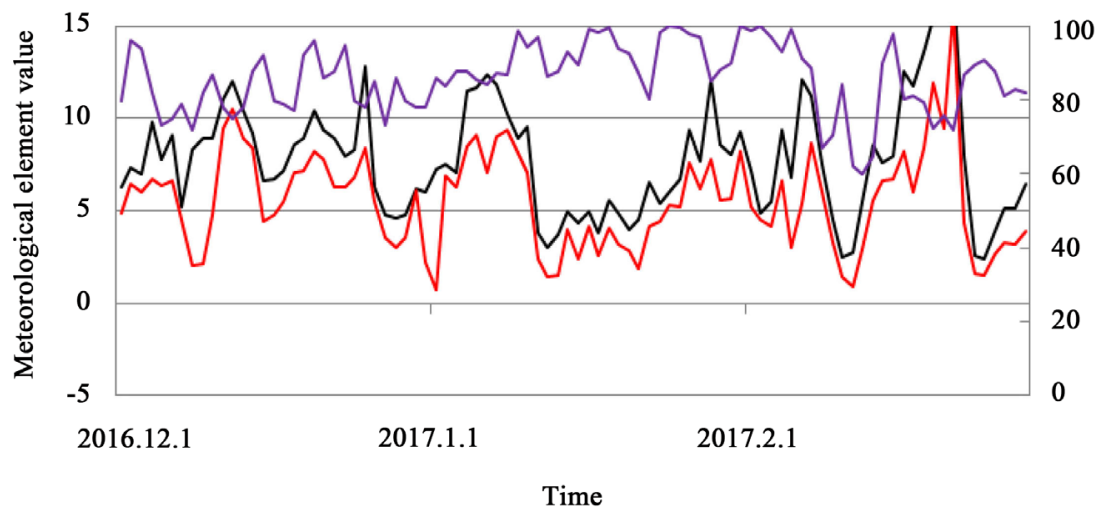

(a1)
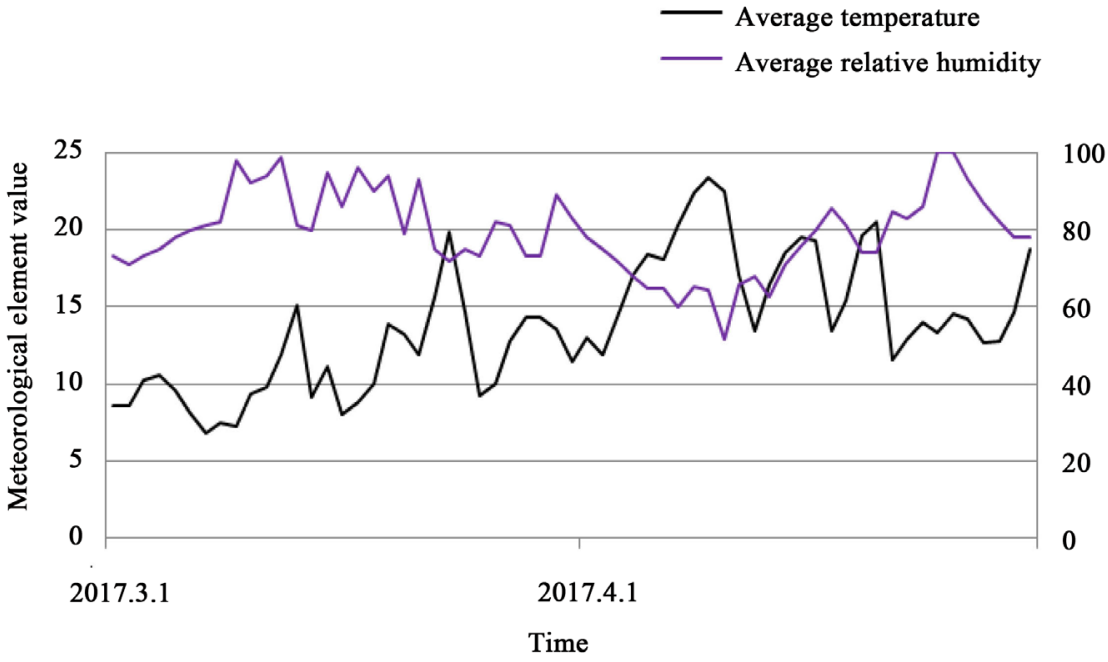

(b1)

-Average temperature

- Extreme minimum temperature

- Average relative humidity

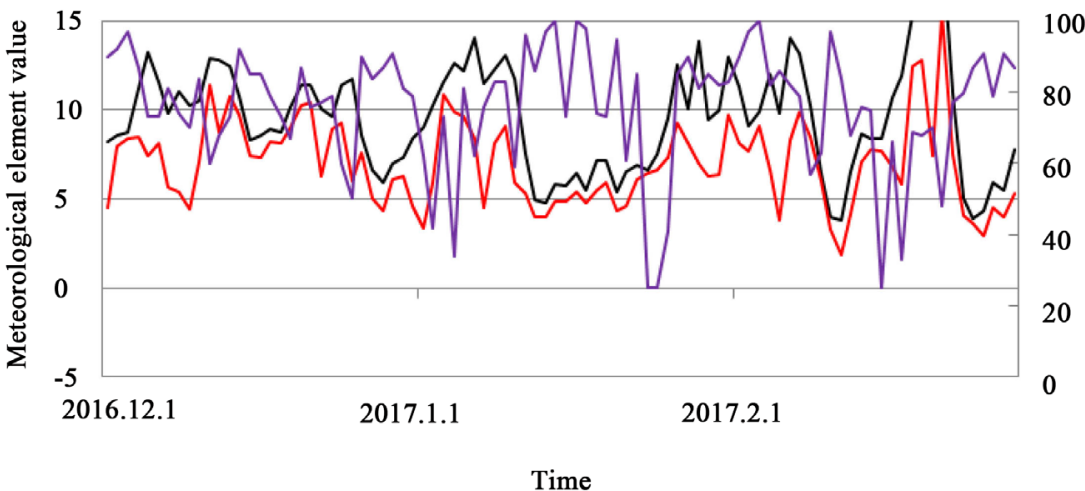

(a2) 


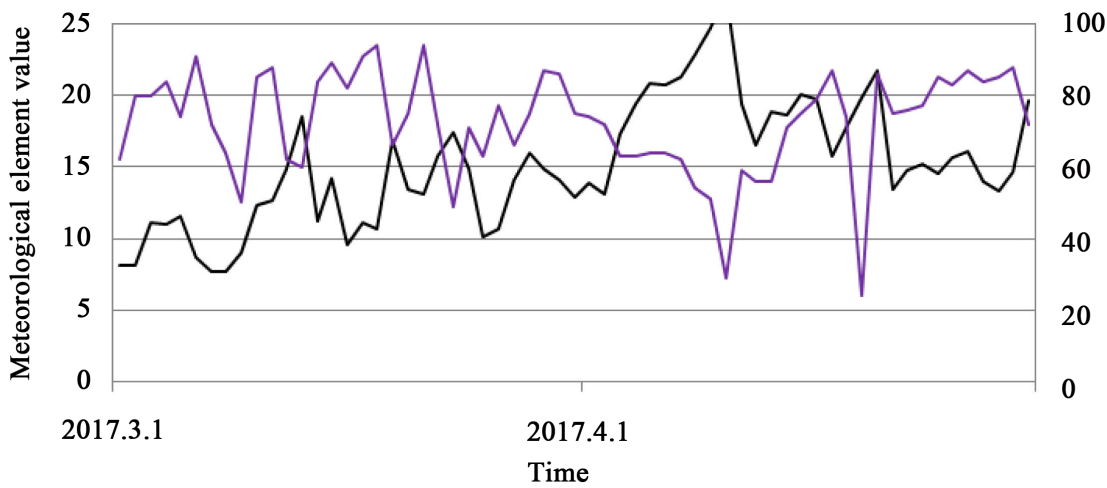

(b2)
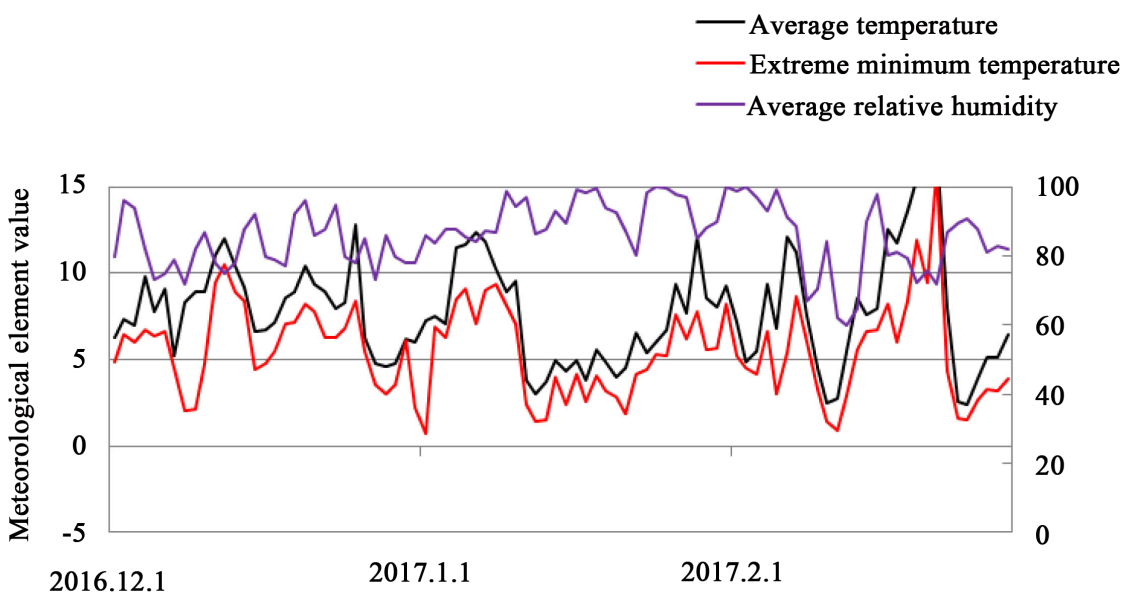

2016.12.1

Time

(a3)

- Average temperature

- Average relative humidity

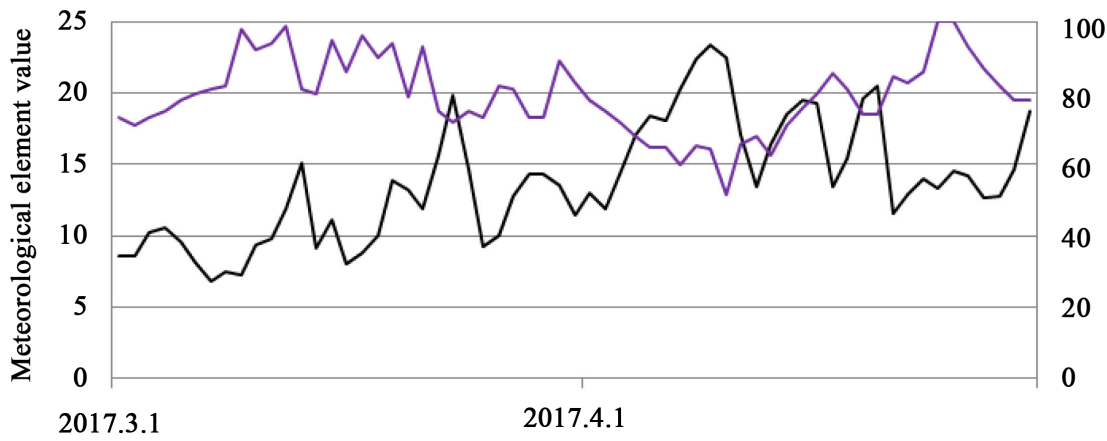

Time

(b3)

Figure 4. Daily meteorological elements change in Langyi ((a1), (b1)), Pugu ((a2), (b2)) and Miluo ((a3), (b3)) bases from December 2016 to April 2017 (unit: temperature is ${ }^{\circ} \mathrm{C}$ Relative humidity is \%). 
expansion of the pathogens of the ulcer disease. However, in the spring of 2017, Langqi occurred two times of low-temperature and high-humidity weather, which occurred in the middle to late mid-March and The average daily temperature for continuous 14 days is $6.8^{\circ} \mathrm{C}-15.1^{\circ} \mathrm{C}$, the daily average relative humidity is $80 \%-98 \%$, and the average temperature for the 8 th day in late April is $11.5^{\circ} \mathrm{C}-14.6^{\circ} \mathrm{C}$, and the daily average relative humidity is $82 \%-100 \%$. Weather (Figure 4(b1)); 2 times of low temperature and high humidity weather occurred in Pugu, respectively, in mid-March and averaged $9.6^{\circ} \mathrm{C}$ to $14.2^{\circ} \mathrm{C}$ for 5 consecutive days, daily average relative humidity of $82 \%$ to $94 \%$ and continuous in late April The average daily temperature of $6 \mathrm{~d}$ is $13.3^{\circ} \mathrm{C}-16.1^{\circ} \mathrm{C}$, and the daily average relative humidity is $83 \%-88 \%$ (Figure $4(\mathrm{~b} 2)$ ). Rice bran also occurs twice in low temperature and high humidity, which appears in early March and is continuous. The average daily temperature of $5 \mathrm{~d}$ is $7.7^{\circ} \mathrm{C}-11.2^{\circ} \mathrm{C}$, The average relative humidity of $88 \%$ to $95 \%$ in late April and $8 \mathrm{~d}$ consecutive daily average temperature of $13.0^{\circ} \mathrm{C}-16.3^{\circ} \mathrm{C}$, daily average relative humidity of $81 \%$ to $95 \%$ of the low-temperature and humid weather (Figure 4(b3)). It can be seen that the meteorological conditions in winter cannot satisfy the proliferation and expansion of the pathogens of ulcer disease, but the tree body should be accompanied by ulcerative pathogens. Once the spring temperature and humidity conditions satisfy the active pathogen of the ulcer disease, the leaves of the red heart kiwifruit can reflect the symptoms of ulcer disease.

\subsection{Changes in Meteorological Elements from the Winter of 2017 to the Spring of 2018 and Their Impact on Ulcer Disease}

From December 1, 2017 to February 28, 2018, the langu, Pugu, Caomi and Mi Fu bases all had a low-temperature and high-humidity weather process. Lang Lang mainly appeared in late January to February 2018. In the late first half of the year, the average temperature was $-2.5^{\circ} \mathrm{C}$ to $1.3^{\circ} \mathrm{C}$ for 10 consecutive days, the minimum temperature for daily extremes was $-4.3^{\circ} \mathrm{C}$ to $-2.1^{\circ} \mathrm{C}$, and the daily average relative humidity was $78 \%$ to $89 \%$ for low temperature rain and snow (Figure 5(a1)). It appears in the late second half of January 2018 to the late first half of February and has an average temperature of $-2.2^{\circ} \mathrm{C}$ to $-0.3^{\circ} \mathrm{C}$ for 11 consecutive days, a minimum daily temperature of $-4.1^{\circ} \mathrm{C}$ to $-2.1^{\circ} \mathrm{C}$, and a daily average relative humidity of $76 \%$ to $92 \%$. In the low temperature rain and snow weather (Figure 5(a2)), the spoon rice mainly appears in the middle of late January 2018 to the late first half of February, and the average temperature for the 14th day is $-4.8^{\circ} \mathrm{C}$ to $2.0^{\circ} \mathrm{C}$, and the daily minimum temperature is $-5.1^{\circ} \mathrm{C}$ to $-2.3^{\circ} \mathrm{C}$. The daily average relative humidity is $77 \%-95 \%$ of low temperature rain and snow weather (Figure 5(a3)). Rice bran mainly occurs in the late second half of January 2018 to the middle of early February and the average temperature on the 8 th day is $-1.8^{\circ} \mathrm{C}-0.3^{\circ} \mathrm{C}$, day. The extreme minimum temperature is $-3.6^{\circ} \mathrm{C}$ to $-2.1^{\circ} \mathrm{C}$, and the daily average relative humidity is $86 \%$ to $94 \%$ of low temperature rain and snow (Figure 5(a4)). It can be seen that the low temperature and high humidity conditions in winter are suitable for the 


\section{- Average temperature}

- Extreme minimum temperature

- Average relative humidity

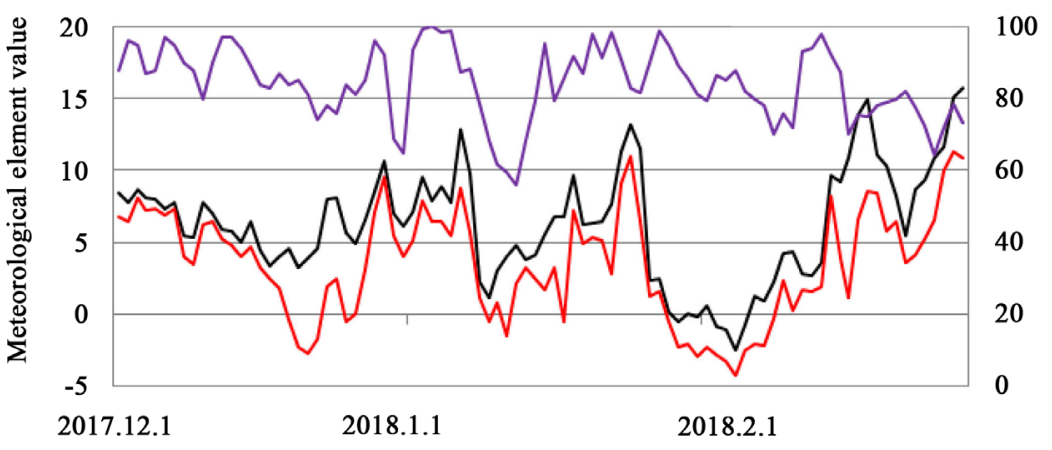

Time

(a1)

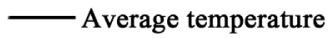

Average relative humidity

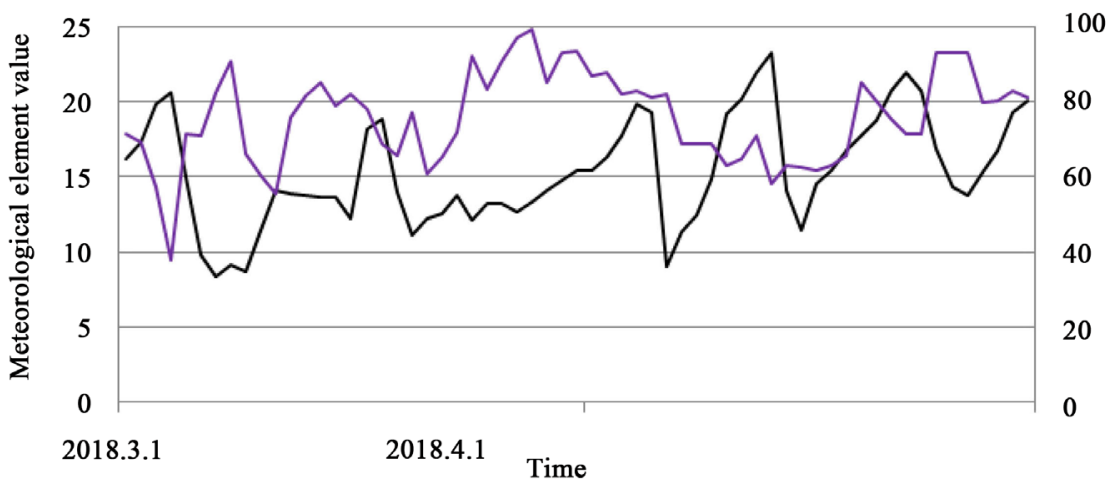

(b1)
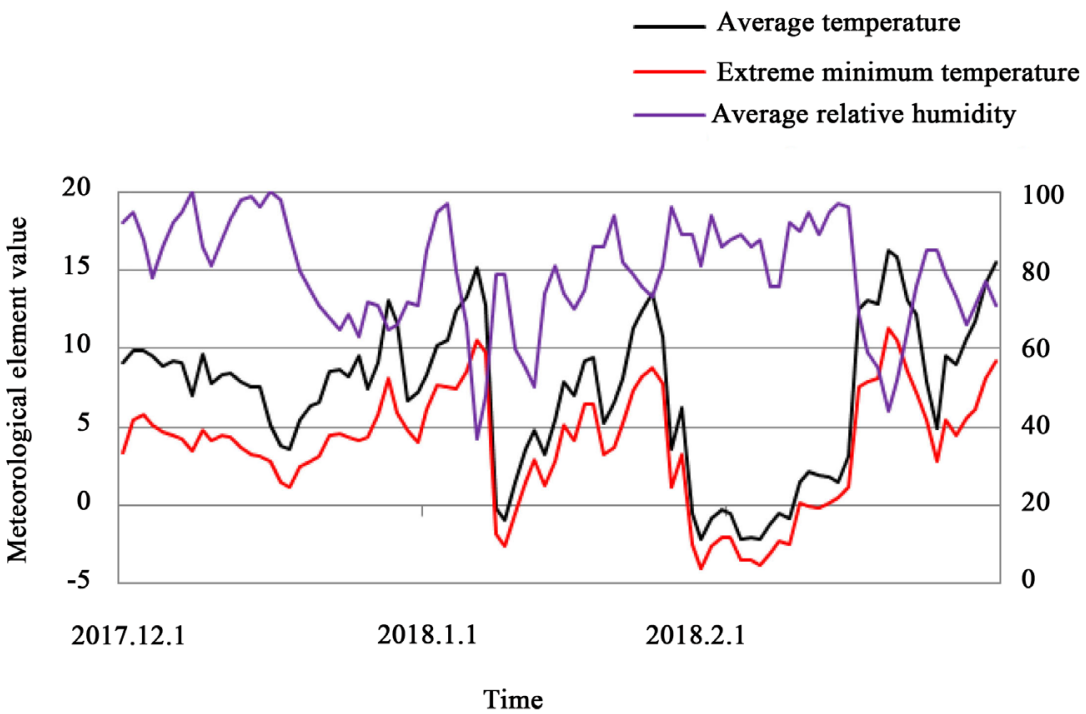

(a2) 
- Average temperature

Average relative humidity

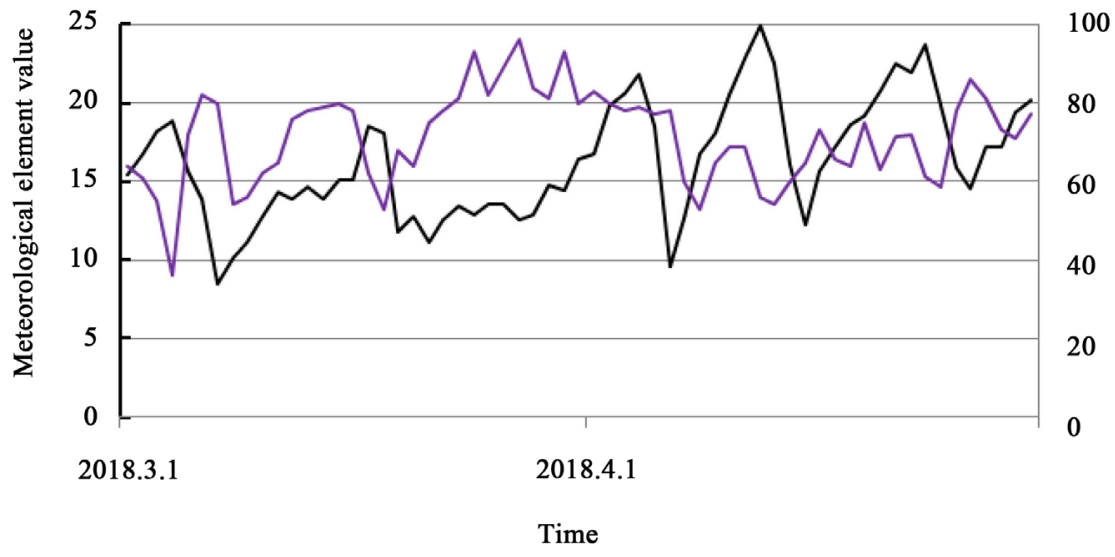

(b2)
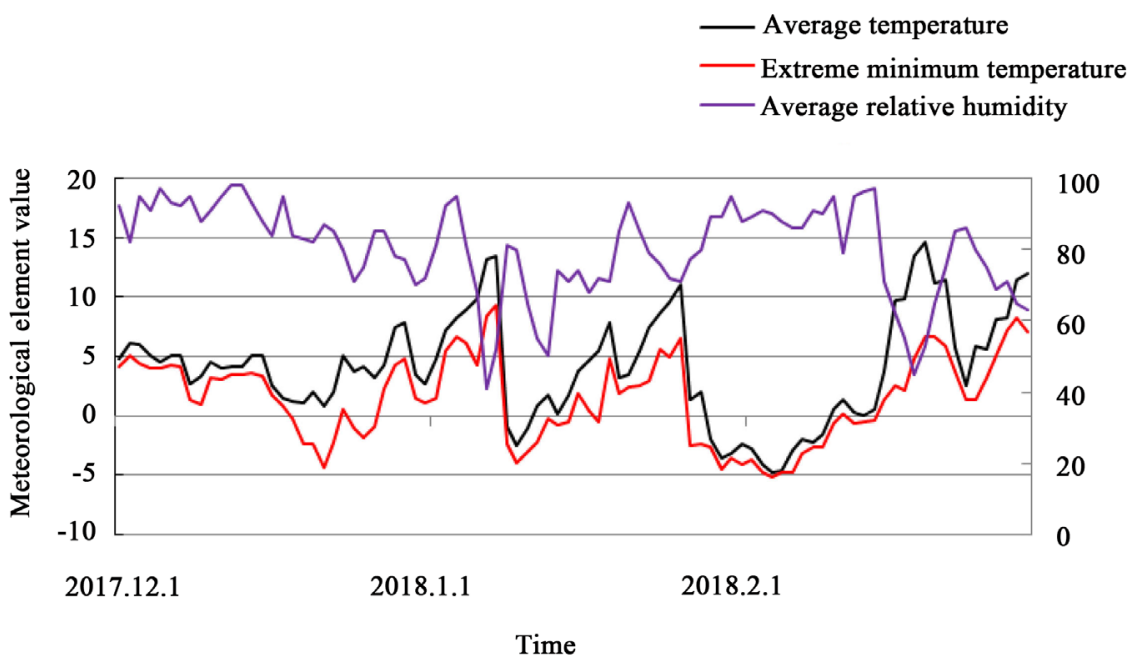

(a3)

Average temperature

Average relative humidity

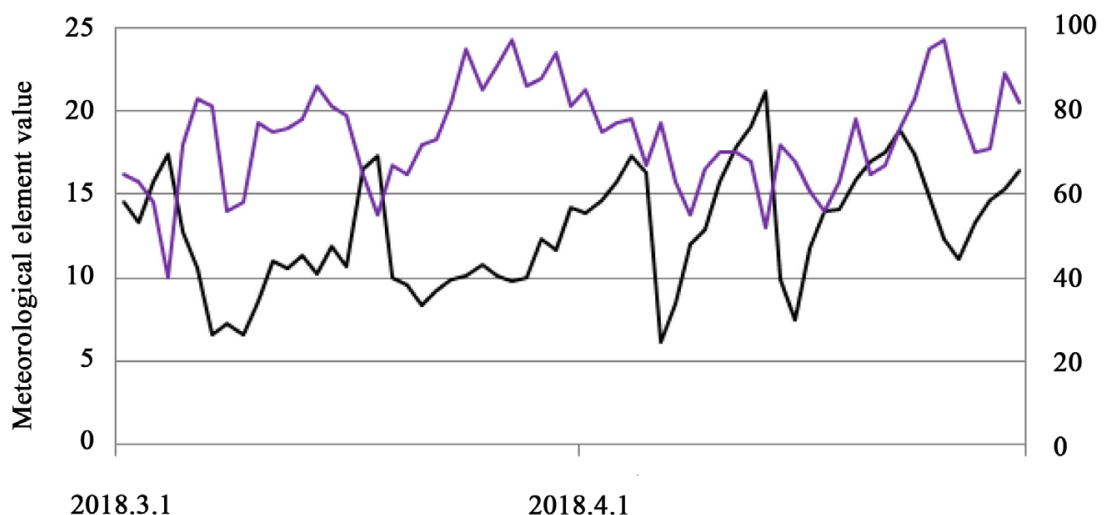

(b3) 


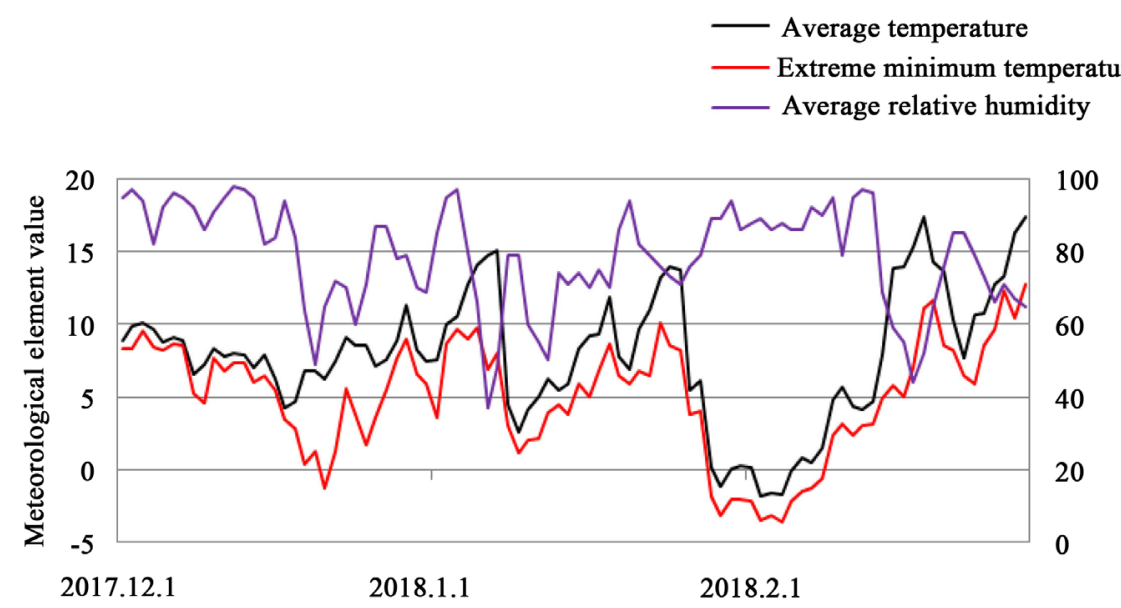

(a4)
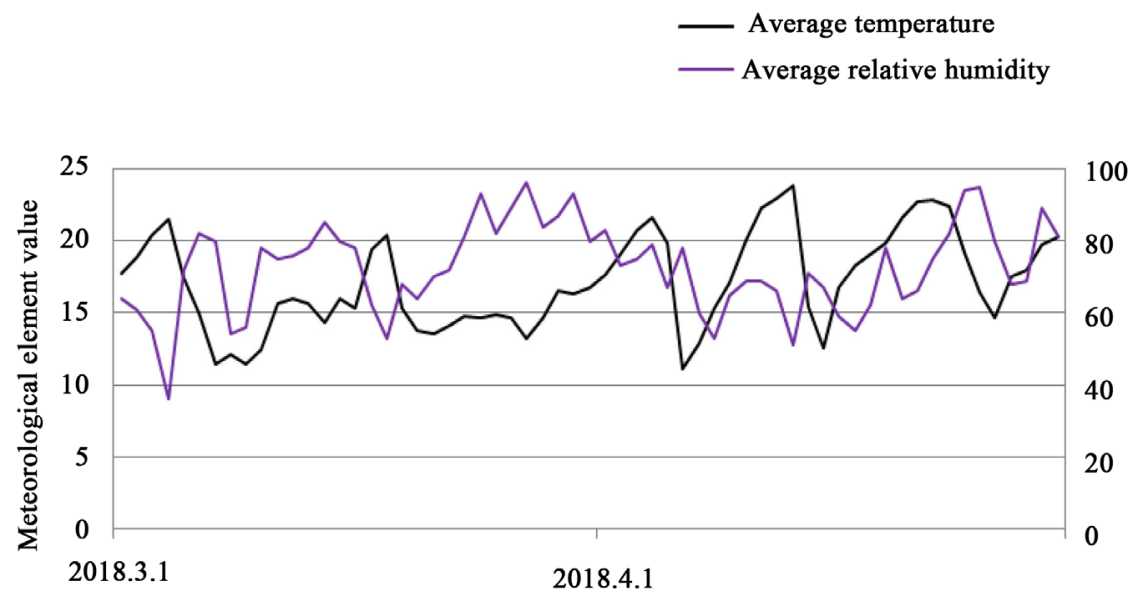

(b4)

Figure 5. Changes in meteorological elements from Langyi ((a1), (b1)), Pugu ((a2), (b2)), Shaomi ((a3), (b3)) and Miluo ((a4), (b4)) bases from December 2017 to April 2018 (unit: Temperature is ${ }^{\circ} \mathrm{C}$, relative humidity is $\left.\%\right)$.

latent, proliferating and spreading of the pathogens of ulcer disease, which creates favorable conditions for the occurrence, development and popularization of spring ulcer disease.

From March 1st to April 30th, 2018, the langu, Pugu, Caomi and Rice bran bases all had a low-temperature and high-humidity weather. Langji mainly appeared in the middle of late March to early April and continued. The average daily temperature on the 11 th day is $12.1^{\circ} \mathrm{C}-17.8^{\circ} \mathrm{C}$, and the daily average relative humidity is $82 \%-100 \%$ in low temperature and high humidity weather (Figure 5(b1)). Pugu mainly appears in the early March to early April and the average temperature for 10 consecutive days. It is a low-temperature and high-humidity weather with a daily average relative humidity of $80 \%$ to $96 \%$ (Figure $5(\mathrm{~b} 2)$ ) of $12.5^{\circ} \mathrm{C}$ to $16.8^{\circ} \mathrm{C}$. The spoon rice mainly appears in the early March to early April and the average temperature is 9.9 to 14.2 for 10 consecutive days. ${ }^{\circ} \mathrm{C}$, daily average relative humidity of $81 \%$ to $97 \%$ of low temperature 
and high humidity weather (Figure 5(b3)), rice bran mainly appeared in the early March to early April and the last 10 days of continuous average temperature of $13.2^{\circ} \mathrm{C}-17.6^{\circ} \mathrm{C}$, daily average The relative humidity is $81 \%$ to $96 \%$ of low temperature and high humidity (Figure 5(b4)). Therefore, suitable temperature and humidity conditions in spring promote the spread of ulcer disease and increase the degree of harm.

\section{Conclusions and Discussion}

\subsection{Conclusion}

1) In winter, when the average daily temperature is $\leq 2^{\circ} \mathrm{C}$ for 5 consecutive days and above, the extreme minimum temperature is $\leq-2^{\circ} \mathrm{C}$, and the average relative humidity is $\geq 75 \%$, the pathogens satisfying the ulcer disease are latent, proliferating and expanding in the plant. It provides favorable conditions for the occurrence and prevalence of spring ulcer disease. Therefore, the meteorological conditions can be used as a meteorological warning indicator for ulcer disease monitoring.

2) When the meteorological conditions in winter meet the survival of ulcer pathogens, red kiwifruit ulcer disease may occur when the daily average temperature of $5 \mathrm{~d}$ and above in spring is $\leq 18^{\circ} \mathrm{C}$ and the average relative humidity is $\geq 80 \%$.

\subsection{Discussion}

This experimental study has met the meteorological conditions for the occurrence of red heart kiwifruit ulcer disease, and many experts have studied (Han et al., 2013; Li et al., 2001; Wang et al., 1998). The annual extremely low temperature $\leq-12^{\circ} \mathrm{C}$ has ulcer disease. Compared with the results, the meteorological warning indicators of the red heart kiwifruit ulcer disease in this study are systematic and complete; and it is basically consistent with the research results of Italian scholars (Serizawa \& Ichikawa, 1993) that the rainy, high-humidity and low-temperature $\left(12^{\circ} \mathrm{C}-18^{\circ} \mathrm{C}\right)$ climate in early spring is conducive to the rapid propagation of PSA pathogens. However, this experiment only selects the main planting area of Guizhou red heart kiwifruit for monitoring, analysis and research. The scope is small, the meteorological conditions of ulcer disease occurrence and epidemic are limited. Whether the meteorological condition is suitable for the national kiwifruit red yang variety planting area, it also needs to be done further monitoring and research.

\section{Acknowledgements}

This study was co-financed by the China Guizhou Provincial Science and Technology Cooperation Project "Climate Experimental Study on Stereo-Specific Agriculture of Karst Mountainous Lands" (52020-2015-01-02), Guizhou Science and Technology Plan Project "Guizhou Red Heart Kiwifruit Refined Climate Zoning and Main Pest and Meteorological Forecasting and Warning System" 
(Qian Ke He NY Zi [2012] 3020).

\section{Conflicts of Interest}

The authors declare no conflicts of interest regarding the publication of this paper.

\section{References}

Balestr, A. G., Renzi, M., \& Mazzaglia, A. (2010). First Report of Bacterial Canker of Actinidia Deliciosa Caused by Pseudomonas Syringae Pv. Actinidiae in Portugal. New Disease Reports, 22, 10. https://doi.org/10.5197/j.2044-0588.2010.022.010

Han, M., Zhang, Z., Chen, L. et al. (2013). Influencing Factors and Prevention Methods of Kiwifruit Ulcer Disease. Hunan Agricultural Sciences, 21, 77-80.

Hyo, S. H., Eun, J. O., \& Young, J. K. (2003). Characterization of Pseudomonas Syringae pv. Actinidiae Isolated in Korea and Genetic Relationship among Coronatione Producing Pathovars Based on Cma U Seguences. Acta Horticultural, 610, 403-408. https://doi.org/10.17660/ActaHortic.2003.610.53

Li, Y., Cheng, H., Fang, S., et al. (2001). Preliminary Study on the Prevalence of Kiwi Bacterial Ulcer Disease. Chinese Journal of Applied Ecology, 12, 355-358.

Liu, S., Tang, X., Wang, Z., et al. (1996). The Occurrence of Kiwifruit Ulcer Disease in Cangxi, Sichuan Province. Chinese Fruit Trees, 1, 25-26.

Serizawa, S., \& Ichikawa, T. (1993). Epidemiology of Bacterial Canker of Kiwifruit. Annual Meeting of the Phytopathological Society of Japan, 59, 460-468.

Wang, Z. (2015). Discussion on the Prevention and Treatment Technology of Kiwifruit Ulcer Disease in Hongyang. China Forestry Deputy Specialty, 135, 38-39.

Wang, Z., Gao, T., Gu, J. et al. (1998). Study on the Main Pathogenic Conditions of Kiwifruit Ulcer Disease. Journal of Anhui Agricultural Sciences, 26, 347-348.

Zhang, C. (2011). Preliminary Study on Tetraploid Induction and Anti-Ulcer Disease Characteristics of Hongyang Kiwifruit. Chongqing: Southwest University.

Zhu, H. (2009). Kiwifruit (p. 231). Beijing: China Forestry Publishing House. 